\title{
TERMOBAROMETRIA E TRAJETÓRIA P-T DE METASSEDIMENTOS DO GRUPO ARAXÁ EM GOIÁS
}

\author{
THERMOBAROMETRY AND P-T PATH OF METASEDIMENTARY ROCKS OF THE ARAXÁ \\ GROUP FROM GOIÁS
}

\author{
Guillermo Rafael Beltran NAVARRO ${ }^{1}$, Antenor ZANARDO ${ }^{1}$, Cibele Carolina \\ MONTIBELLER ${ }^{2}$, Thaís Güitzlaf LEME ${ }^{2}$, Fabiano Tomazini da CONCEIÇÃO ${ }^{3}$ \\ ${ }^{1}$ Instituto de Geociências e Ciências Exatas, Departamento de Petrologia e Metalogenia, Universidade Estadual Paulista, Campus de \\ Rio Claro. Email: guillermo.navarro@unesp.br, antenor.zanardo@unesp.br, \\ ${ }^{2}$ Pós-Graduação em Geociências e Meio Ambiente, Instituto de Geociências e Ciências Exatas, Departamento de Petrologia e \\ Metalogenia, Universidade Estadual Paulista. Email: cibele.cm@outlook.com, thais.guitzlaf@hotmail.com, \\ ${ }^{3}$ Instituto de Geociências e Ciências Exatas, Departamento de Planejamento Territorial e Geoprocessamento, Universidade Estadual \\ Paulista. Emaill: fabiano.tomazini@unesp.br

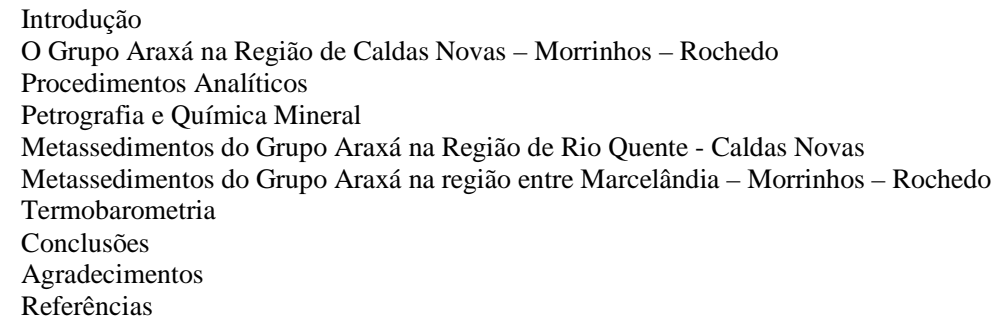

RESUMO - Na região sudeste do estado de Goiás (região de Caldas Novas - Marcelândia - Morrinhos - Rochedo) afloram metassedimentos pelíticos, psamo-pelíticos e psamíticos atribuídos ao Grupo Araxá. Na região de Caldas Novas (Domínio Caldas Novas) as associações minerais relacionadas ao pico metamórfico são típicas da transição da fácies xisto verde superior/anfibolito inferior e o auge metamórfico calculado indica temperaturas entre $500^{\circ} \mathrm{C}$ a $570^{\circ} \mathrm{C}$ e pressões entre $7-8 \mathrm{kbar}$, no campo de estabilidade da cianita. As associações minerais relacionadas ao pico metamórfico na região entre Marcelândia- Morrinhos - Rochedo (Domínio Araxá Oeste) são típicas da fácies anfibolito médio a superior e os cálculos termobarométricos mostram pico metamórfico a $600^{\circ} \mathrm{C}$ $670^{\circ} \mathrm{C}$ e 9-11 kbar, em condições de fácies anfibolito, zona da cianita. Os cálculos com o geotermômetro Zr em rutilo, realizados para pressões de $10 \mathrm{kbar}$, apontam temperatura mínima de $611^{\circ} \mathrm{C}$ e máxima de $692^{\circ} \mathrm{C}$. A trajetória $P-T$ inferida, com base nos dados texturais e termobarométricos, é horária. As associações minerais observadas e os dados termobarométricos sugerem um zoneamento metamórfico progressivo de E para W no Grupo Araxá na região, e sugerem que os conjuntos possuem histórias metamórficas diferentes e que o zoneamento metamórfico é resultado da estruturação tectônica.

Palavras chave: Faixa Brasília, Grupo Araxá, Química Mineral, Termobarometria.

ABSTRACT - In the southeastern region of Goiás state (Caldas Novas - Morrinhos - Rochedo region) outcrop psammitic, psamopelitic and pelitic metasediments related to the Araxá Group. In the Caldas Novas region (Caldas Novas Domain), the mineral associations related to the metamorphic peak are typical of the upper greenschist facies/lower amphibolite facies and the calculated metamorphic peak indicates temperatures between $500^{\circ} \mathrm{C}$ and $570^{\circ} \mathrm{C}$ and pressures between $7-8 \mathrm{kbar}$, kyanite zone. The mineral associations related to the metamorphic peak in the region between Marcelândia - Morrinhos - Rochedo (Araxá West Domain) are typical of medium to upper amphibolite facies and the thermobarometric calculations show metamorphic peak at $600^{\circ} \mathrm{C}-670^{\circ} \mathrm{C}$ and 9-11 kbar, under conditions of amphibolite facies, kyanite zone. The calculations with the geothermometer Zr-in-Rt, performed for pressures of $10 \mathrm{kbar}$, indicate a minimum temperature of $527^{\circ} \mathrm{C}$ and a maximum of $688^{\circ} \mathrm{C}$. The P-T path, inferred based on textural and thermobarometric data, is clockwise. The mineral associations observed in congruence with mineral chemistry analyzes and thermobarometric studies suggest a progressive metamorphic zoning from E to W in the Araxá Group in the Caldas Novas Morrinhos - Rochedo region. However, the thermobarometric data suggest that the sets have different metamorphic histories and that metamorphic zoning is a result of tectonic structuring.

Keywords: Brasília Belt, Araxá Group, Mineral Chemistry, Thermobarometry.

\section{INTRODUÇÃO}

O Grupo Araxá foi definido na região de Araxá (Minas Gerais), sob a denominação de Formação Araxá (Barbosa, 1955) e, posteriormente, Barbosa et al. (1970a, b) estendem o "Grupo Araxá” para a porção centro-sul do estado de Goiás. Na porção sul do estado de Goiás, trabalhos posteriores (como por exemplo, Araújo et al., 1980; Fuck \&
Marini, 1981; Ianhez et al., 1983; Valente, 1986) mantém a definição e as unidades litológicas do Grupo Araxá seguindo a proposta de Barbosa et al. (1970b).

Embora não exista uma divisão oficial, o Grupo Araxá pode ser dividido em pelo menos duas faixas: i) uma abaixo das unidades litológicas do Complexo Anápolis-Itauçu/ 
Associação Ortognáissica Migmatítica, que se estende até a região de Passos (MG) e ii) uma

Goiânia até a região de Corumbaíba, acima, que ocorre desde a região de Trindade - Paraná (Figura 1).

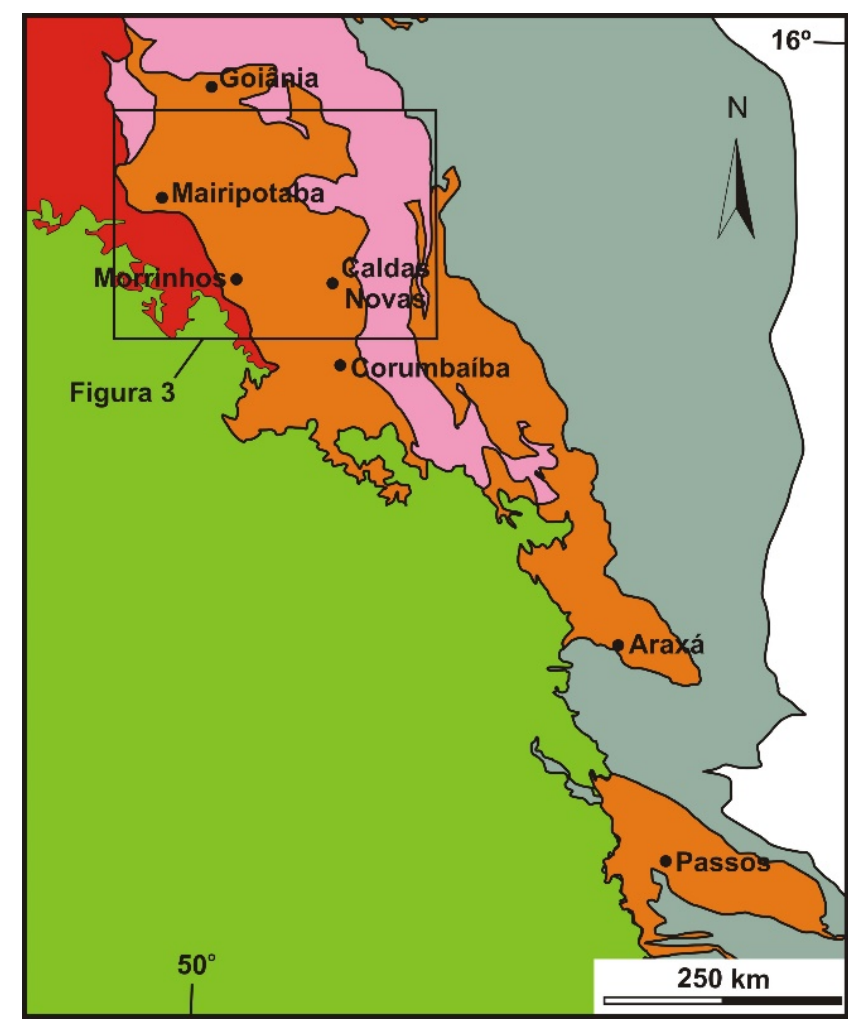

\section{BACIA DO PARANÁ}

\section{ARCO MAGMÁTICO DE GOIÁS}

\section{FAIXA BRASÍLIA}

\section{Zona Interna}

Grupo Araxá e rochas associadas.

\section{Zona Externa}

Grupos Paranoá, Canastra e Formações Vazante e Ibiá e porções de seu embasamento.

Granulitos e rochas associadas (Complexo Granulítico Anápolis-Itauçu e Associação Ortognáissica Migmatítica).

\section{CRÁTON DO SÃO FRANCISCO}

Figura 1 - Mapa esquemático de parte da Faixa Brasília, mostrando a distribuição espacial do Grupo Araxá (Modificado de Hasui, 2012).

Estudos sobre a proveniência de metassedimentos do Grupo Araxá entre Caldas Novas e Morrinhos mostram que estes são derivados de rochas ígneas félsicas, possuem assinaturas químicas de sedimentos derivados de rochas formadas em arcos magmáticos e sugerem que os sedimentos do pacote superior foram depositados em bacias tipo fore arc (Navarro et al., 2013, 2017). Idades modelo $\mathrm{T}_{\mathrm{DM}} \mathrm{Nd}$ de rochas metassedimentares desta unidade mostram sistematicamente dois intervalos de distribuição (Figura 2), um com idades modelo variando entre 1,0 - 1,54 Ga (predominando valores $<1,40 \mathrm{Ga}$ ) e outro variando entre 1,61 - 2,60 Ga (predominando valores $>1,7$ ), enquanto as idades $U / P b$ obtidas em cristais de zircão detríticos para estas rochas são predominantemente neoproterozoicas $(<1,0$ $\mathrm{Ga}$ ), com contribuições restritas de fontes mais antigas (>1,0 Ga) (Figura 2).

Estas idades sugerem que a fonte dos metassedimentos corresponde a rochas relacionadas ao Arco Magmático de Goiás (idades mais jovens) e a terrenos mesopaleoproterozoicos (idades mais antigas) (Pimentel et al., 1999, 2001; Piuzana et al., 2003; Simões, 2005; Klein, 2008; Navarro et al., 2013, 2017, 2018).

Apesar do avanço do conhecimento sobre os metassedimentos do Grupo Araxá, poucos são os trabalhos em Goiás sobre a evolução metamórfica e trajetória P-T das rochas deste grupo.

O conhecimento de trajetórias P-T é importante, pois pode indicar o registro das condições impostas por todo processo metamórfico, e deste modo, inferir a evolução tectônica/metamórfica de um orógeno. A proposta do presente trabalho é a investigação das condições de metamorfismo e da trajetória P-T do Grupo Araxá, na região de Caldas Novas - Morrinhos - Rochedo, Goiás.

\section{O GRUPO ARAXÁ NA REGIÃO DE CALDAS NOVAS - MORRINHOS - ROCHEDO}

O Grupo Araxá na região de Caldas Novas Morrinhos tem recebido ao longo do tempo diversas denominações e divisões (Lacerda
Filho et al., 1999; Moreira et al., 2008; Simões, 2005). Neste artigo adotaremos em parte as divisões e denominações propostas por Simões 
(2005). Na região de Rio Quente - Caldas Novas, a Serra de Caldas corresponde a uma janela estrutural, relacionada a um domo braquianticlinal (Barbosa et al., 1970b; Drake Jr., 1980), onde afloram metassedimentos relacionados ao Grupo Paranoá sobrepostos por metassedimentos do Grupo Araxá (Figura 3).

Esta estrutura possui forma ovalada, alongada na direção NNW, com cerca de 18 km de comprimento e $12 \mathrm{~km}$ de largura. A parte central do domo é constituída por uma sequência de baixo grau metamórfico (fácies xisto verde, zona da biotita) (Simões, 2005).

Os dados estruturais mostram que a estrutura braquianticlinal é desenvolvida em estágios precoces da fase deformacional que gerou a foliação principal (Sn) (Simões et al., 2003; Simões, 2005).

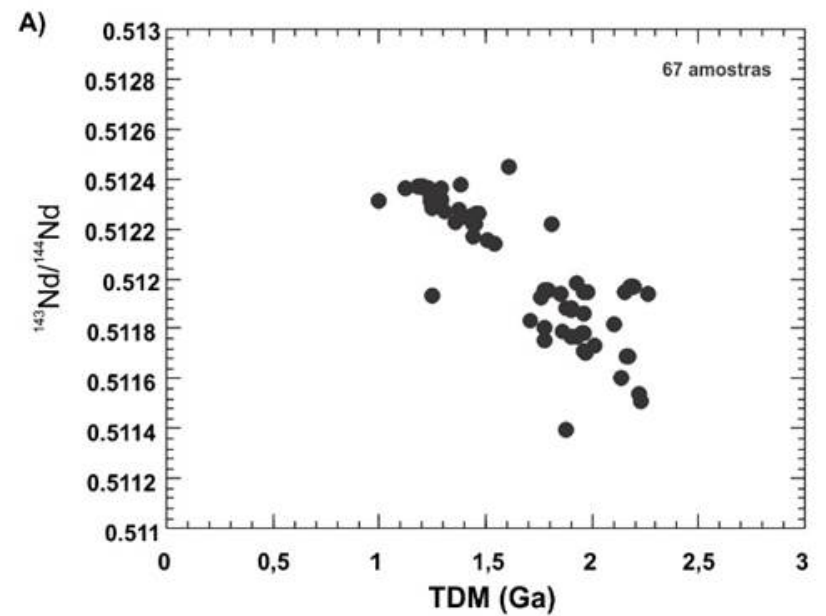

C)

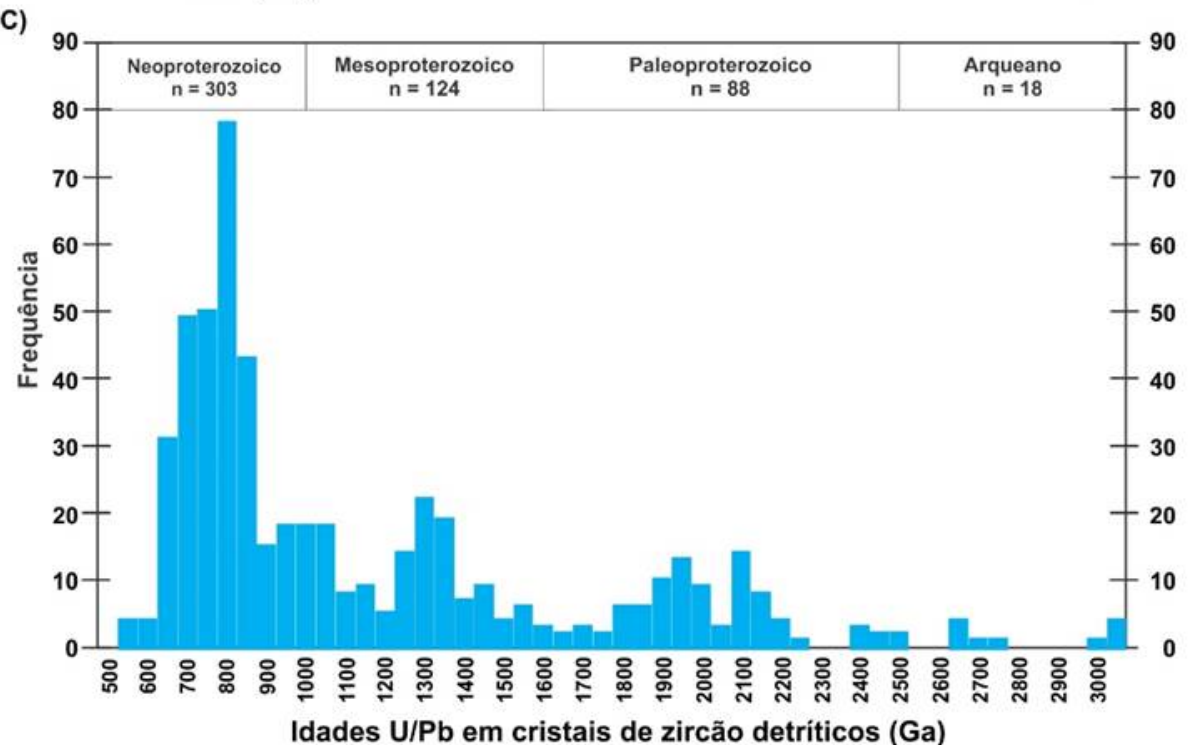

Figura 2 - A) Composição isotópica ${ }^{143} \mathrm{Nd} /{ }^{144} \mathrm{Nd}$ e idades modelo e B) Variação dos valores de $\varepsilon N d$ no tempo geológico das amostras de metassedimentos do Grupo Araxá em Goiás. C) Idades U/Pb de cristais de zircões detríticos de metassedimentos do Grupo Araxá em Goiás. I - Composição isotópica de rochas do Arco Magmático de Goiás (Pimentel \& Fuck, 1992; Navarro \& Zanardo, 2007). II - Composição isotópica de metassedimentos do Grupo Araxá, na porção sul do Estado de Goiás (Pimentel et al., 2000; Navarro et al., 2013, 2017, 2018). III - Composição isotópica de rochas do Cráton do São Francisco (Pimentel et al., 2001). IV- Composição isotópica de rochas do Maciço Mediano de Goiás (Pimentel et al., 1996; Sato, 1998).

O contato desta unidade com os metassedimentos do Grupo Araxá é tectônico, marcada por cavalgamento. O Grupo Araxá, na região do Domo de Caldas (denominado informalmente como Domínio Caldas Novas DCN, segundo Simões 2005), é constituído por intercalações de xistos feldspáticos ou não (clorita-biotita-muscovita xisto, biotitamuscovita-quartzo xisto, biotita/muscovitaquartzo xisto, clorita-muscovita-quartzo xisto localmente com granada; muscovita-quartzo xisto, muscovita-biotita-quartzo xisto, cloritamuscovita-biotita xisto, subordinadamente quartzito e muscovita quartzito) e gnaisses de origem paraderivada (biotita paragnaisse com muscovita e granada; biotita-muscovita paragnaisse com ou sem granada; muscovita paragnaisse com biotita).

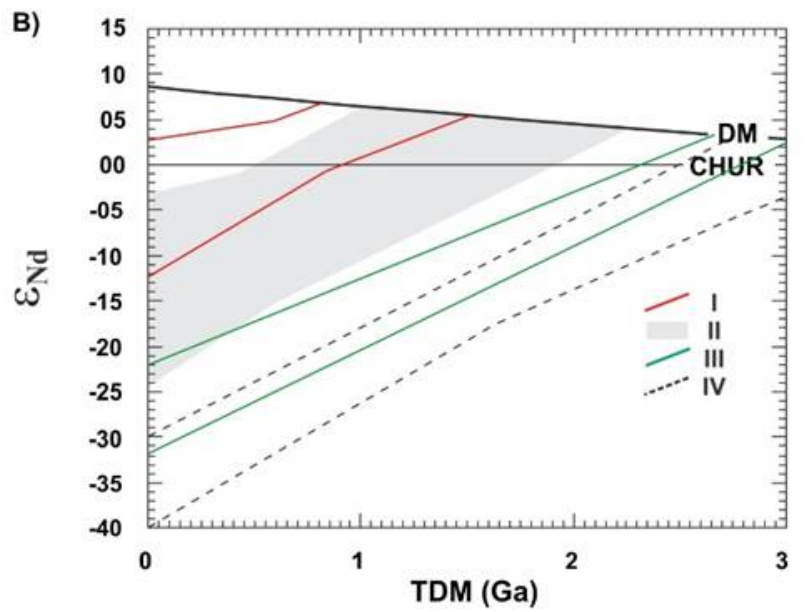




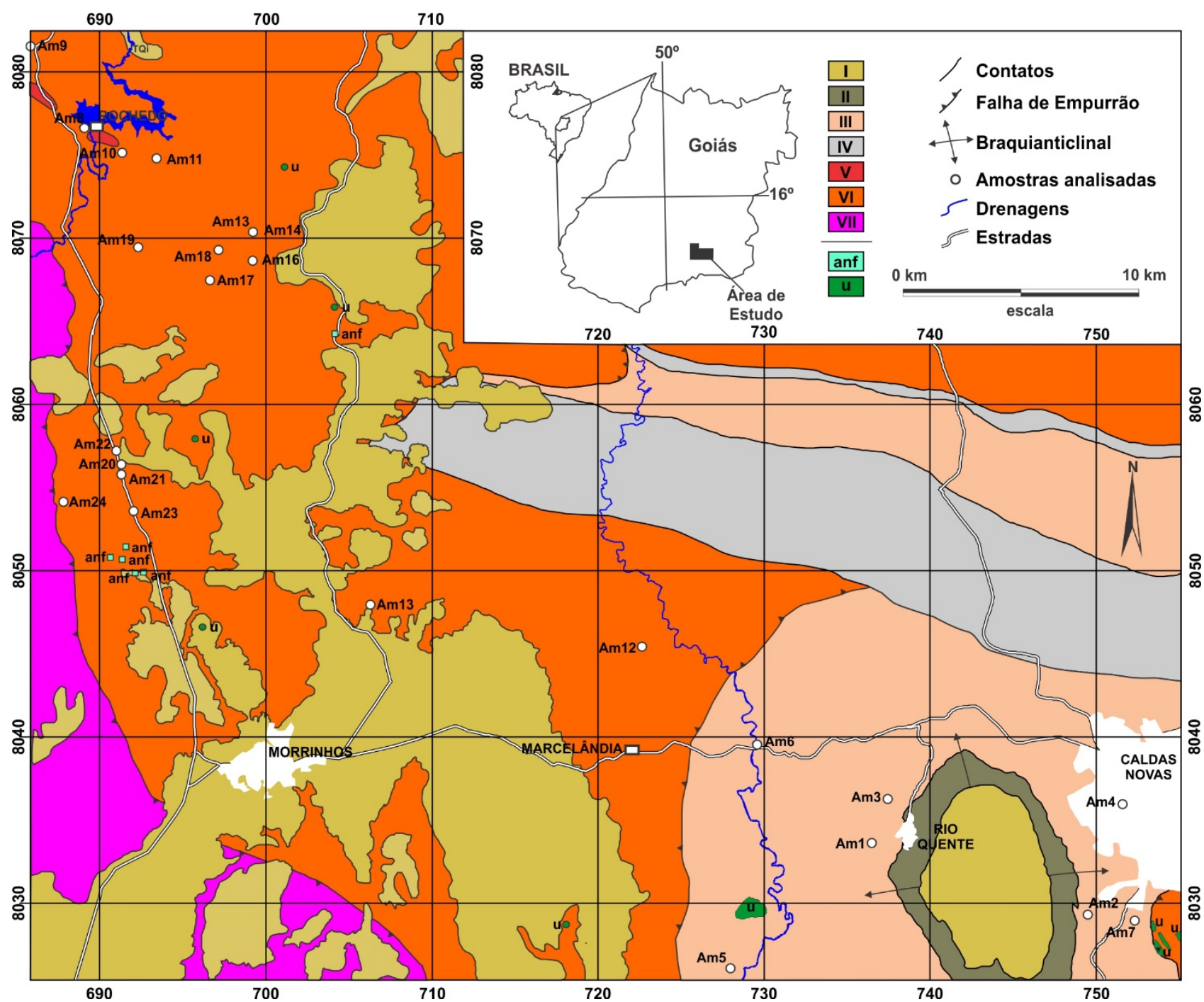

Figura 3 - Mapa geológico simplificado da área de estudo mostrando a localização das amostras utilizadas nos cálculos termobarométricos (modificado de Simões 2005). I - Coberturas, II - Grupo Paranoá, III - Domínio Caldas Novas, IV Domínio Sequência Quartzítica, V - Granitóides Tipo Rochedo, VI - Domínio Araxá Oeste, VII - Arco Magmático de Goiás, anf - rochas metamáficas, $u$ - rochas metaultramáficas (metaultramáficas Tipo Morro Feio).

Acima desta unidade ocorre uma faixa constituída por intercalações de quartzo xisto, muscovita xisto, biotita xisto, clorita-muscovitaquartzo xisto feldspático ou não com biotita e com ou sem granada, muscovita-quartzo xisto com intercalações métricas de muscovita quartzito/quartzito e de metabásicas/metaultrabásicas e, mais raramente, intercalações de grafita xisto/filito.

Sobre esta faixa ocorre uma sequência de xistos variados (denominada de Domínio Araxá Oeste - DAW, por Simões, 2005) constituída por biotita-muscovita xisto, clorita-muscovitaquartzo xisto feldspático ou não, com ou sem granada, muscovita-quartzo xisto, muscovita quartzito, biotita-quartzo xisto, biotita xisto, muscovita-biotita xisto, em geral quartzosos, localmente com intercalações de paragnaisses (biotita-clorita-muscovita paragnaisse, biotitamuscovita paragnaisse, biotita paragnaisse) e quartzito (quartzito e muscovita quartzito); subordinadamente ocorrem intercalações de metaultramáficas (clorita-actinolita/tremolita xisto, talco xisto) e metabásicas (anfibolito). Segundo Simões (2005), esta unidade faz parte do DAW, mas neste trabalho, esta faixa será considerada como agrupada ao DCN, com o ligeiro deslocamento do contanto entre o DCN e o DAW para oeste, em função do grau metamórfico observado.

A norte ocorre uma sequência de metassedimentos (denominada informalmente de Domínio Sequência Quartzítica por Simões, 2005) constituídos por muscovita-quartzo xisto, muscovita-clorita-quartzo xisto com ou sem cloritoide, biotita-muscovita-quartzo xisto, com intercalações de quartzitos micáceos e lentes de meta calcários, sericita quartzito, grafita xisto, grafita-sericita-quartzo xisto, clorita xisto, granada-muscovita xisto, com intercalações de 
quartzitos micáceos ou não, intercalações de muscovita xisto e quartzo xisto.

Para oeste, próximo à região de Marcelândia até a região de Morrinhos/Rochedo, os metassedimentos do Grupo Araxá (Domínio Araxá Oeste - DAW, Simões, 2005) predominantes são muscovita/biotita xisto, biotita xisto, muscovita/ biotita paragnaisse, normalmente com granada e localmente com hornblenda, cianita e estaurolita. Associadas a estes metassedimentos ocorrem metabásicas (anfibolito, granada anfibolito) e metaultramáficas (tremolita xisto, serpentinito, talco xisto, clorita xisto, etc.).

Na região de Rochedo - Mairipotaba ocorre uma extensa faixa, orientada no sentido NW - SE, de quartzito (quartzito micáceo, quartzito, granada quartzito, etc.), intercalado com metassedimentos pelíticos (granada-muscovita/ biotita xisto, muscovita/biotita xisto feldspáticos ou não; muscovita/biotita paragnaisse). Nesta região também ocorrem diversos corpos graníticos classificados como do tipo S ou MPG, gerados a partir da fusão parcial de metassedimentos do Grupo Araxá (Navarro et al., 2014a, b).

\section{PROCEDIMENTOS ANALÍTICOS}

Foram selecionadas 24 amostras do Grupo Araxá para estudos de química mineral e estudos termobarométricos.

Parte das análises de química mineral (6 amostras) foi compilada de trabalhos anteriores (Navarro et al., 2011; Simões, 2005). As análises por microssonda eletrônica do restante das amostras foram realizadas no Laboratório de
Microssonda Eletrônica do Departamento de Petrologia e Metalogenia (DPM/UNESP). Os cálculos termobarométricos foram feitos utilizando o software THERMOCALC, modo Average-PT (Powell \& Holland, 1994) e o termômetro $\mathrm{Zr}$ em rutilo (Zack et al., 2004a; Tomkins et al., 2007). A localização das amostras é apresentada na figura 3.

\section{PETROGRAFIA E QUÍMICA MINERAL}

\section{Metassedimentos do Grupo Araxá na Região de Rio Quente - Caldas Novas (DCN)}

As amostras selecionadas para estudos termobarométricos são metassedimentos pelíticos a psamo-pelíticos representados por xistos, e a localização das amostras é apresentada na Figura 3. Os xistos são anisotrópicos com estrutura xistosa, normalmente com bandamento e/ou laminação difusos, em geral dobrados, com a presença frequente de formas sigmoidais, clivagem de crenulação, dobras de arrasto e dobras intrafoliares.

A textura é variada, apresentando domínios granoblásticos sacaroidais, transicionais entre granoblásticos e lepidoblásticos, até perfeitamente lepidoblásticos. A alternância entre os domínios lepidoblásticos e granoblásticos define um bandamento descontínuo (So), geralmente paralelo a Sn, localmente transposto por Sn (So//Sn-1).

A granulação também é bastante variável, sendo que os domínios granoblásticos apresentam grãos de tamanho entre $100 \mu \mathrm{m}$ e $500 \mu \mathrm{m}$ de diâmetro, predominando granulação de 300-400 $\mu \mathrm{m}$. Já os domínios lepidoblásticos, em geral, apresentam cristais menores que 100 $\mu \mathrm{m}$, podendo variar a até cristais maiores que $2500 \mu \mathrm{m}$. Localmente, apresentam poiquiloblastos e pseudomorfos de granada.

São constituídos por quartzo (35-60\%), feldspatos (0-20\%), muscovita (15-30\%), e subordinadamente por biotita (3-10\%), clorita (5-16\%), apatita (0-5\%), granada (0-4\%), epidoto (0-4\%), titanita (0-2\%) e minerais opacos (1-3\%), com traços de allanita, carbonato, turmalina, hidróxidos de ferro, zircão e minerais radioativos não identificados.

A biotita ocorre como cristais subedrais a anedrais, com dimensões médias da ordem de $300-500 \mu \mathrm{m}$, e localmente pode alcançar dimensões de $1000 \mu \mathrm{m}$. Os cristais ocorrem orientados segundo o bandamento composicional (foliação Sn-1), que geralmente é paralelo a $\mathrm{Sn}$, e localmente ocorrem dobrados e/ou formando arcos poligonais desenhando zonas de charneira de dobras intrafoliares rompidas (crenulação Sn).

Alguns cristais de biotita ocorrem intercrescidos com muscovita e/ou clorita (Figura 4A), e outros ocorrem como cristais dispostos ortogonalmente à foliação, sugerindo duas gerações, uma mais antiga (associada ao auge metamórfico) que foi corroída por muscovita e clorita, e outra que cresceu tardi- a pósdesenvolvimento da foliação Sn (Figura 4B).

Os cristais de biotita analisados possuem razão ( $\mathrm{Fe} / \mathrm{Fe}+\mathrm{Mg}$ ) variando entre 0,568 - 0,669 e são classificados dominantemente como siderofilita (Figura 5A) e subordinadamente como annita (tanto os cristais menores como os porfiroblastos). 

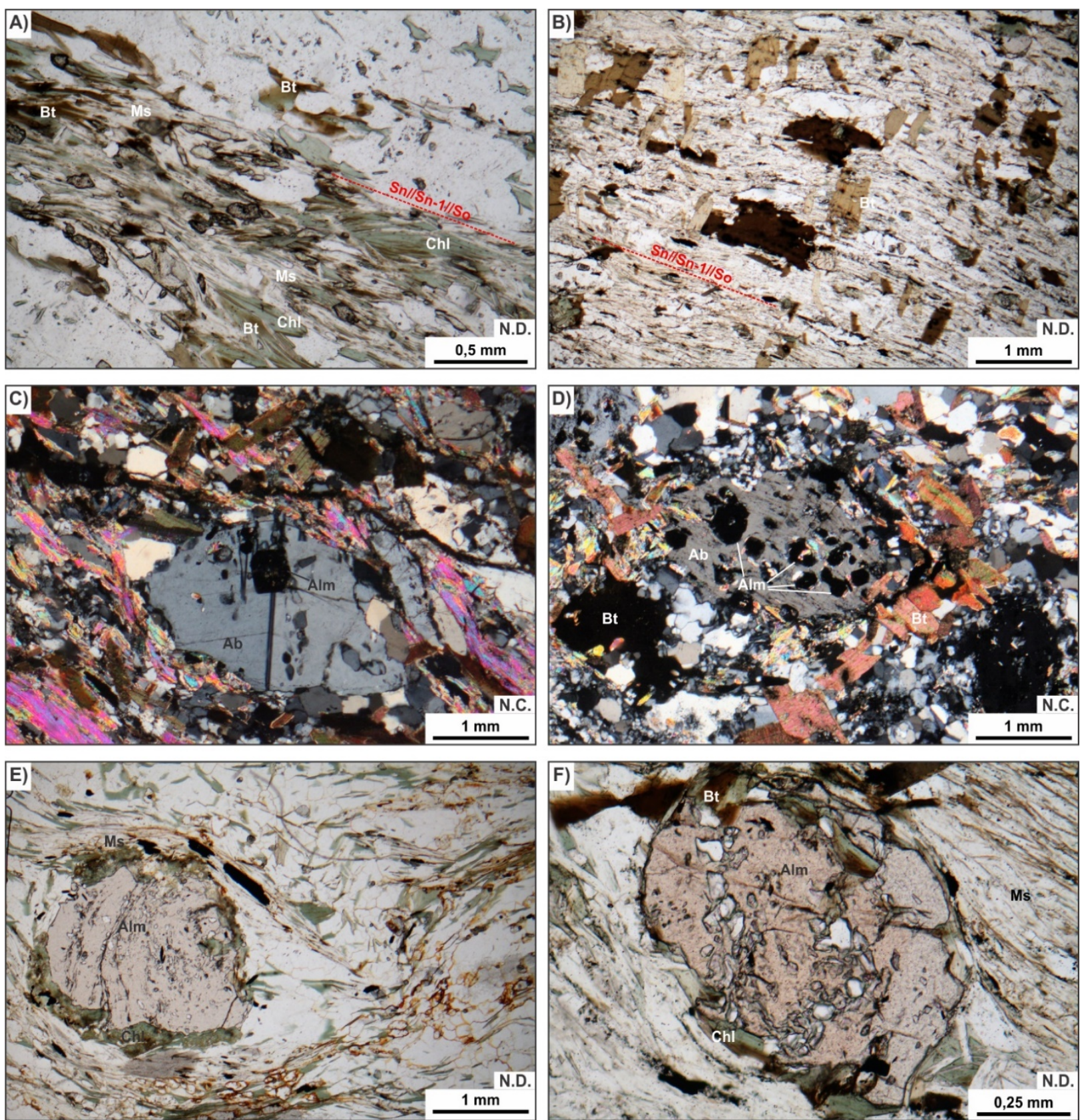

Figura 4 - A) cristais de biotita intercrescidos com muscovita e clorita. B) cristais de biotita tardi- a pósdesenvolvimento da foliação Sn. C), D) cristais de albita com inclusões de almandina. E), F) cristais de granada com bordas parcialmente alteradas para clorita e biotita. Ab: albita. Alm: almandina. Bt: biotita. Chl: clorita. Ms: muscovita. N.D. nicóis descruzados. N.C. nicóis cruzados.

Apenas em uma amostra os cristais de biotita possuem razão $(\mathrm{Fe} / \mathrm{Fe}+\mathrm{Mg})$ menor, variando entre $0,490-0,506$ e são classificados como siderofilita - eastonita (as análises caem no limite entre os dois campos) (Figura 5A). O teor de Ti é baixo $(<1 \%)$ e varia entre 0,227 a 0,269 átomos por unidade de fórmula (a.p.u.f.).

Os cristais de plagioclásio analisados são anedrais, localmente subedrais, com dimensões médias da ordem de $300-400 \mu \mathrm{m}$, chegando a 2000 - $3000 \mu \mathrm{m}$. Ocorrem em agregados granoblásticos junto ao quartzo e/ou junto a filossilicatos, localmente parcialmente saussuritizados e com inclusões de titanita e minerais opacos. Alguns cristais maiores possuem inclusões de granada euédrica (Figura 4C) e de trilhas de opacos. Quimicamente, os cristais analisados apresentam composição variando entre albita e oligoclásio, sendo classificados dominantemente como albita $\left(\mathrm{Ab}_{100-0,915}\right)$, e não exibem zoneamento químico.

Os cristais com composição de oligoclásio $\left(\mathrm{Ab}_{0,855-0,709}\right)$ são raros (Figura 6A). Apenas na amostra (Am2) a maioria dos cristais apresentam composição predominante de oligoclásio $\left(\mathrm{Ab}_{0,715-}\right.$ 0,736 ) sugerindo que as temperaturas atingiram condições acima do hiato da peristerita, ou que se tratam de cristais detríticos preservados. 
A)

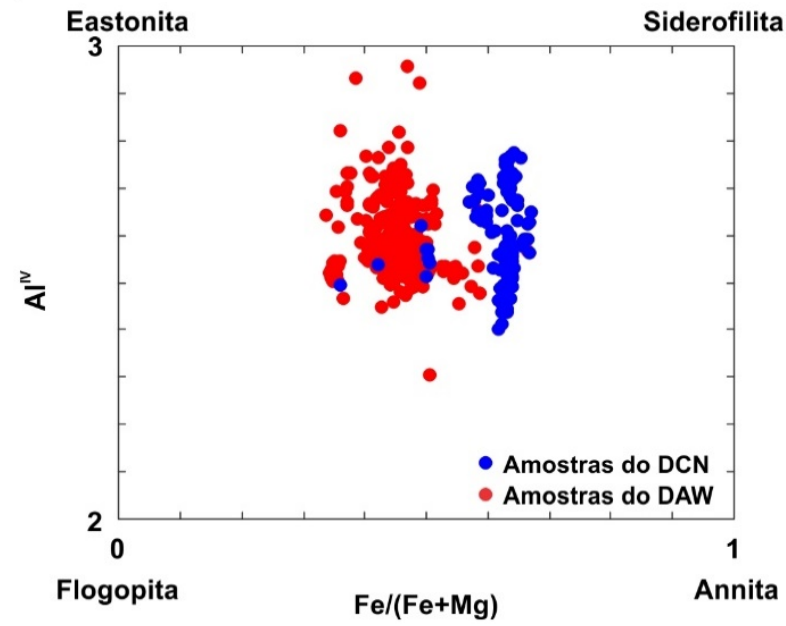

B)

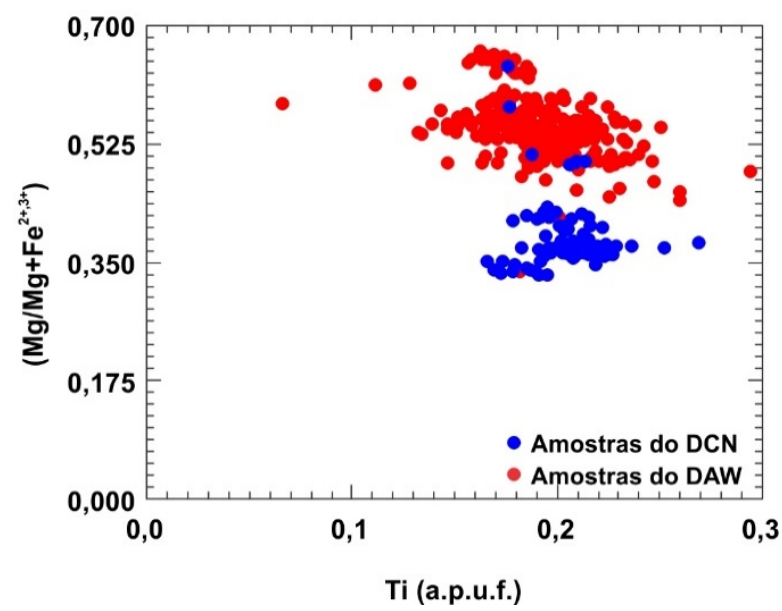

Figura 5 - A) Diagrama de classificação de cristais de biotita analisados e, B) variação do teor de $\mathrm{X}_{\mathrm{Mg}}$ e Ti (a.p.u.f) em cristais de biotita analisados.

A)

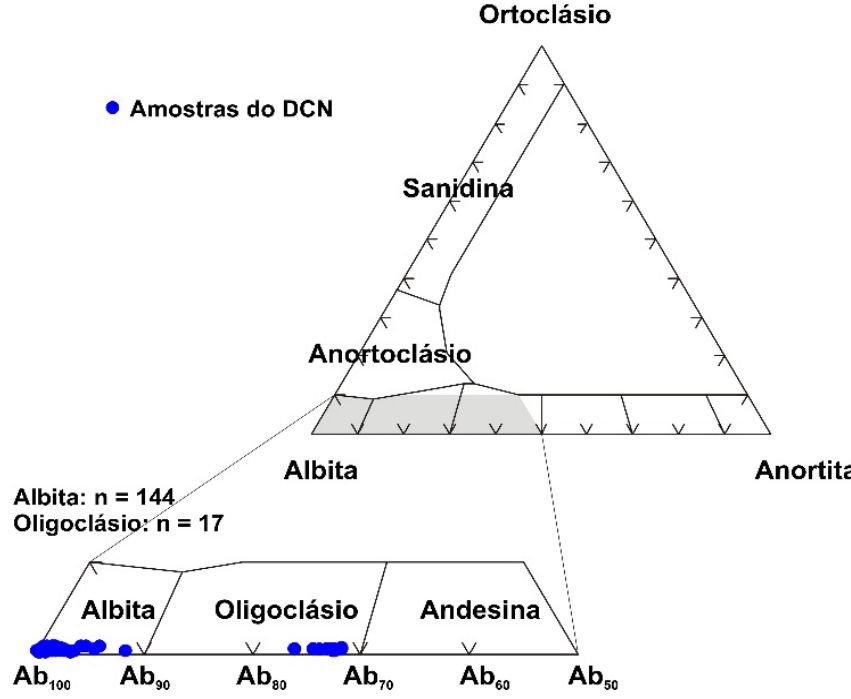

B)

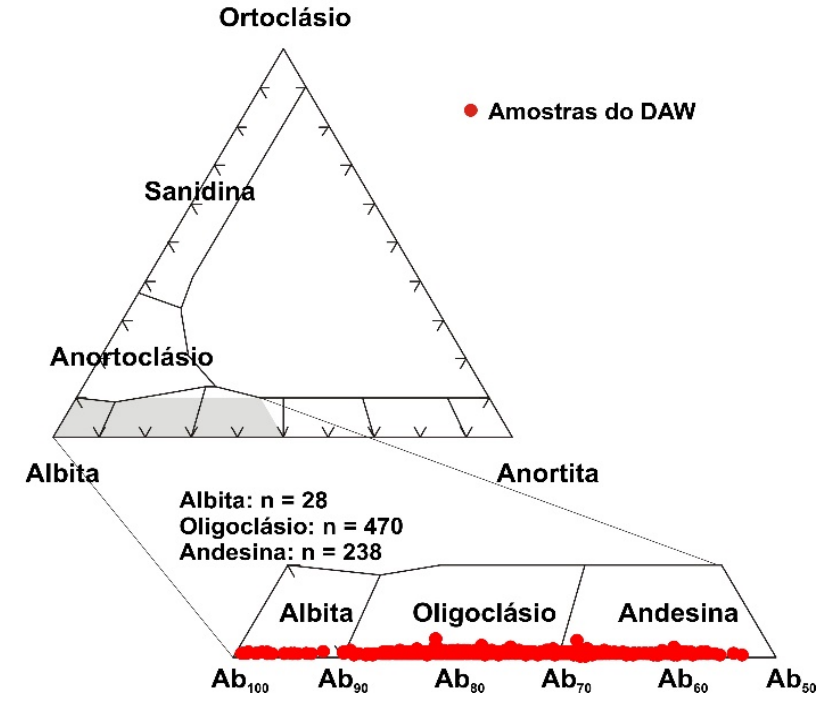

Figura 6 - A) Diagrama de classificação de cristais de plagioclásio analisados na região de Caldas Novas - Rio Quente. B) Diagrama de classificação de cristais de plagioclásio analisados do Grupo Araxá na região de Marcelândia Morrinhos - Rochedo.

A muscovita ocorre como cristais subedrais a anedrais, com dimensões médias da ordem de $200-400 \mu \mathrm{m}$, e localmente pode alcançar dimensões de $600 \mu \mathrm{m}$. Os grãos ocorrem orientados segundo o bandamento composicional (foliação Sn-1//So), que geralmente é paralelo a $\mathrm{Sn}$; localmente ocorrem dobrados e/ou formando arcos poligonais desenhando zona de charneira de dobras intrafoliares rompidas (crenulação Sn). Alguns cristais de muscovita ocorrem intercrescidos com biotita sugerindo que parte dos cristais de muscovita é de alteração de cristais de biotita. Os cristais de muscovita possuem relação $\mathrm{Si} / \mathrm{Al}^{\mathrm{IV}}$ variando entre 1,114 - 1,305 a.p.u.f, razão $\mathrm{Al}^{\mathrm{IV}} / \mathrm{Al}^{\mathrm{VI}}$ variando entre 0,470 - 0,545 a.p.u.f., razão $\mathrm{X}_{\mathrm{Mg}}$ entre 0,363 - 0,555 e relação
$\mathrm{Al}^{\mathrm{VI}} / \mathrm{Al}^{\mathrm{VI}}+\mathrm{Fe}^{3+}$ entre $0,870-0,953$, classificadas dominantemente como fengita. Possuem baixos conteúdos de $\mathrm{Ti}$ (0,012 - 0,062 a.p.u.f), com teores de $\mathrm{K}$ variando entre 0,739 a 0,897 a.p.u.f..

Os cristais de epidoto são anedrais a subedrais (às vezes ocorrem envolvendo pequenos a minúsculos cristais de allanita metamíctica), com dimensões da ordem de 150 a $500 \mu \mathrm{m}$ (localmente atingem dimensões da ordem de $1000 \mu \mathrm{m})$ e geralmente ocorrem dispersos nos domínios granoblásticos e lepidoblásticos. Também ocorrem inclusos em plagioclásio (produto de saussuritização). O teor de Ca varia entre 1,994 - 2,002 a.p.u.f., de $\mathrm{Al}$ entre 2,332 - 2,665 a.p.u.f. e de $\mathrm{Fe}^{3+}$ entre 0,353 - 0,704 a.p.u.f. A concentração de $\mathrm{Fe}^{3+}$ e $\mathrm{Al}$ 
indica uma composição intermediária entre os membros finais epidoto - clinozoisita (Figura 7A).

A clorita é comum nas amostras do DCN, e ocorre normalmente intercrescida com biotita ou na borda de cristais de granada, bem como em cristais isolados dispersos. Os cristais são

A)

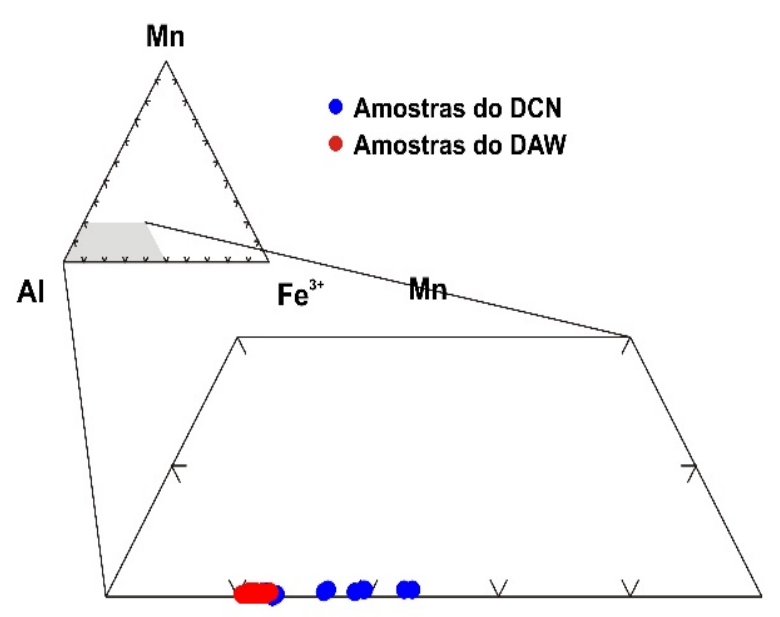

Al anedrais a subedrais (com dimensões da ordem de $300-500 \mu \mathrm{m}$ ) sugerindo que parte da clorita é produto de retrometamorfismo e parte está em equilíbrio. Quimicamente são classificadas, segundo o diagrama de Hey (1954), principalmente como ripidolitas (Figura 7B).

B)

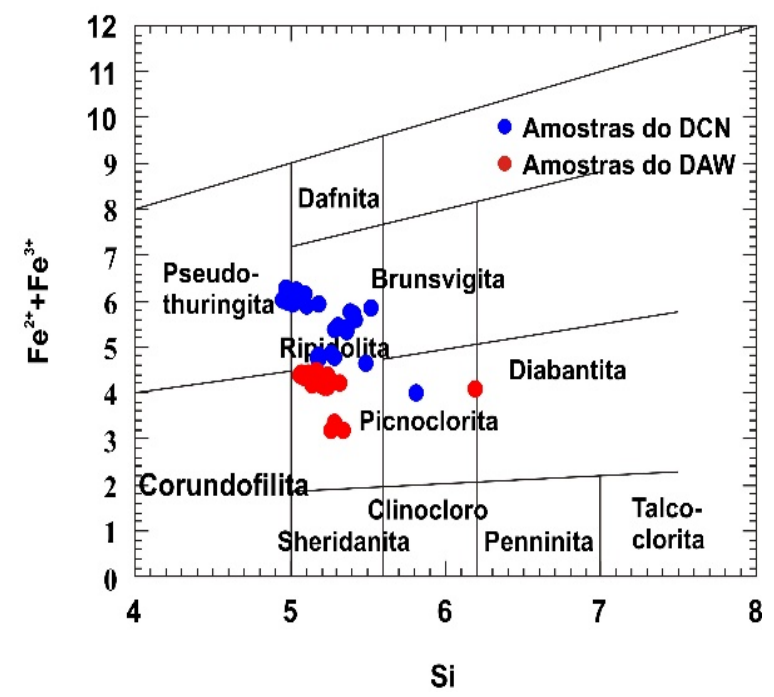

Figura 7 - A) Diagrama de classificação de cristais de epidoto analisados. B) Diagrama de classificação de cristais de clorita analisados (modificado de Hey, 1954).

A granada constitui cristais pequenos (dimensões médias da ordem de 500-1000 $\mu \mathrm{m})$ a relativamente grandes (diâmetro da ordem de $2000-2500 \mu \mathrm{m})$. Ocorre dispersa pela lâmina (cristais isolados), geralmente os maiores cristais são poiquiloblásticos (inclusões de quartzo e minerais opacos), comumente mostram formas anedrais corroídas (bordas alteradas para clorita e biotita - Figura 4E, F), e também ocorre como inclusões em cristais de plagioclásio. São granadas ricas na molécula de almandina (alm $\left.{ }_{51,015-76,885}\right)$ seguido pela molécula de grossulária (grs9,358-33,477). O teor de espessartita, andradita e piropo é variável ( and $_{1,482}$ 6,795; $\mathrm{py}_{1,477-7,156}$; $\mathrm{sps}_{1,146-26,370}$ ), ora predominando um ou outro (Figura 8).

As granadas inclusas nos cristais de plagioclásio geralmente são euedrais a subedrais, com dimensões da ordem de $300-$ $500 \mu \mathrm{m}$ e não exibem corrosão. Os cristais de granada inclusos em cristais de plagioclásio analisados possuem composição semelhante. São granadas ricas na molécula de almandina (alm51,015-76,885) e de grossulária (grs 2,758 31,553). O teor de espessartita, andradita e piropo é variável $\left(\mathrm{and}_{0,513-18,806}\right.$; py 2,332-6,658;

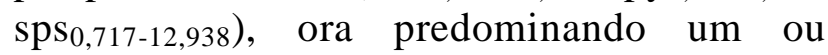
outro.

\section{Metassedimentos do Grupo Araxá na região entre Marcelândia-Morrinhos-Rochedo(DAW)}

As amostras selecionadas para estudos termobarométricos são metassedimentos pelíticos a psamo-pelíticos representados por xistos e paragnaisses, e a localização das amostras é apresentada na Figura 3. Os xistos e paragnaisses são anisotrópicos, inequigranulares, com estrutura xistosa, normalmente com bandamento e/ou domínios lenticulares, podem ou não estar dobrados, com presença frequente de formas sigmoidais, clivagem de crenulação, dobras de arrasto e dobras intrafoliares.

A textura é variada, apresentando domínios granoblásticos, transicionais entre granoblásticos e lepidoblásticos, até perfeitamente lepidoblásticos. São rochas de granulação bastante variável, predominando granulação fina a média (granulação da ordem de $350-600 \mu \mathrm{m})$, podendo variar até cristais maiores com cerca de $3000 \mu \mathrm{m}$. Localmente, apresentam porfiroblastos de granada (podendo atingir cerca de $7000 \mu \mathrm{m}$ de diâmetro). São constituídos por quartzo (25-60\%), feldspatos (tr-40\%), muscovita (5-30\%), biotita (5-20\%) e subordinadamente por clorita (tr-10\%), apatita (tr$3 \%)$, granada (0-10\%), epidoto (0-4\%), titanita (0$2 \%)$ e minerais opacos (1-3\%), com traços de allanita, carbonato, turmalina, hidróxidos de ferro, zircão e minerais radioativos não identificados. 

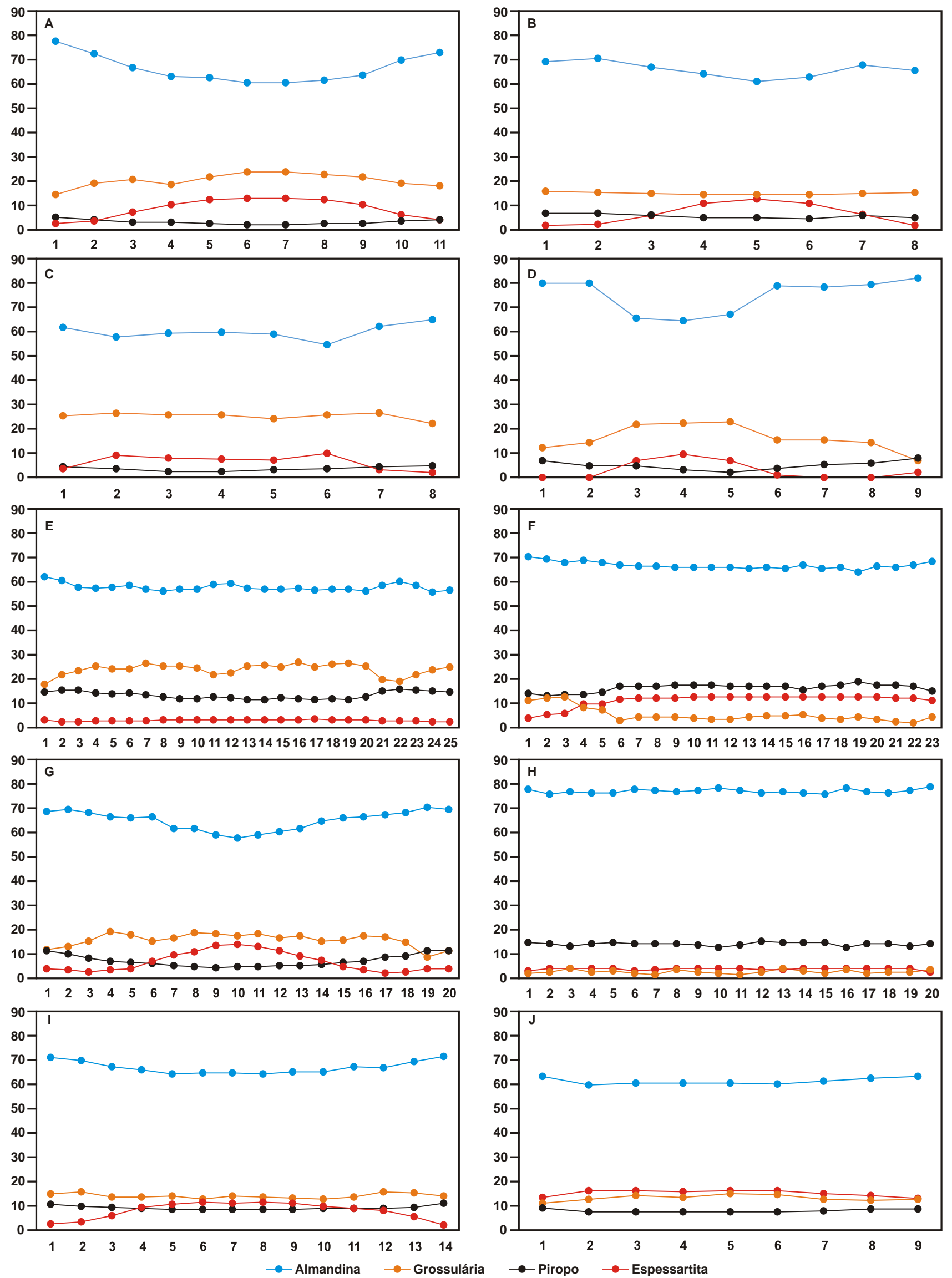

Figura 8 - Perfis de granadas do Grupo Araxá. A), B), C), D) granadas do DCN. E), F), G), H), I), J) granadas do DAW.

A biotita ocorre como cristais subedrais a $300-500 \mu \mathrm{m}$, e localmente pode alcançar anedrais, com dimensões médias da ordem de dimensões de $1000 \mu \mathrm{m}$. 
Os grãos ocorrem orientados segundo ao bandamento composicional (foliação Sn-1), que geralmente é paralelo a $\mathrm{Sn}$, e localmente ocorrem dobrados e/ou formando arcos poligonais desenhando zona de charneira de dobras intrafoliares rompidas (crenulação Sn).

Alguns cristais de biotita ocorrem intercrescidos com muscovita e clorita sugerindo que esta foi corroída por muscovita e clorita. Quimicamente, os cristais de biotita analisados possuem menor razão $(\mathrm{Fe} / \mathrm{Fe}+\mathrm{Mg})$ que as biotitas do Grupo Araxá na região de Caldas Novas -Rio Quente, e são classificadas dominantemente como eastonita $\left(\mathrm{X}_{\mathrm{Mg}}=0,410-\right.$ $0,500)$, sendo que algumas análises caem no campo da siderofilita $\left(\mathrm{X}_{\mathrm{Mg}}=0,500-0,662\right)$. $\mathrm{O}$ teor de Ti é baixo $(<1 \%)$ e varia entre 0,066 a 0,295 a.p.u.f, semelhante às biotitas do Grupo Araxá na região de Caldas Novas -Rio Quente (Figura 5A, B).

Os cristais de plagioclásio analisados são anedrais, localmente subedrais, com dimensões médias da ordem de 300 - $600 \mu \mathrm{m}$, e localmente pode alcançar dimensões de 2000 - $2500 \mu \mathrm{m}$. Ocorrem em agregados granoblásticos junto ao quartzo e/ou junto aos filossilicatos. Quimicamente, os cristais analisados apresentam composição variando entre albita e andesina, classificados dominantemente como oligoclásio/andesina $\left(\mathrm{Ab}_{0,55-0,88}\right)$ (Figura $\left.6 \mathrm{~B}\right)$, sendo raros os cristais com composição de albita ( $\left.A b_{0,94-0,99}\right)$, não exibindo zoneamento químico. As composições albíticas estão relacionadas ao retrometamorfismo.

A muscovita ocorre como cristais subedrais a anedrais, com dimensões médias da ordem de $200-400 \mu \mathrm{m}$, localmente chegando a $1500 \mu \mathrm{m}$. Ocorrem orientadas segundo o bandamento composicional (foliação Sn-1), que comumente é paralelo a $S n$, localmente ocorrem dobradas e/ou formando arcos poligonais desenhando zona de charneira de dobras intrafoliares rompidas (crenulação $\mathrm{Sn}$ ).

Alguns cristais de muscovita ocorrem intercrescidos com biotita, na borda de cristais de cianita, plagioclásio e granada, sugerindo que parte dos cristais da muscovita é produto de alteração destes minerais (retrometamorfismo).

Os cristais de muscovita possuem relação $\mathrm{Si} / \mathrm{Al}^{\mathrm{IV}}$ variando entre $1,063-1,232$ a.p.u.f, razão $\mathrm{Al}^{\mathrm{IV}} / \mathrm{Al}^{\mathrm{VI}}$ variando entre 0,499 - 0,575 a.p.u.f., razão $X_{M g}$ entre 0,381 - 0,611 e relação
$\mathrm{Al}^{\mathrm{VI}} / \mathrm{Al}^{\mathrm{VI}}+\mathrm{Fe}^{3+}$ entre 0,875 - 0,969, sendo classificadas dominantemente como fengita. Possuem baixos conteúdos de Ti $(0,011$ - 0,057 a.p.u.f.), com teores de $\mathrm{K}$ variando entre 0,681 a 0,886 a.p.u.f.

Os cristais de epidoto são anedrais a subedrais (às vezes ocorrem envolvendo pequenos cristais de allanita metamíctica), com dimensões da ordem de 150 a $500 \mu \mathrm{m}$ (localmente atingindo dimensões da ordem de $1000 \mu \mathrm{m})$ e, geralmente ocorrem dispersos nos domínios granoblásticos e lepidoblásticos (Figura 9A). Também ocorrem inclusos em plagioclásio (produto de saussuritização). O teor de Ca varia entre 1,982 - 2,048 a.p.u.f., de $\mathrm{Al}$ entre 2,589 - 2,687 a.p.u.f. e de Fe3+ entre 0,310 - 0,361 a.p.u.f. A concentração de $\mathrm{Al}$ é maior que a de $\mathrm{Fe} 3+$, classificando os cristais analisados como clinozoisita (Figura 7A).

A clorita ocorre normalmente intercrescida com biotita ou na borda de cristais de granada e/ou anfibólio, indicando tratar-se de produto de retrometamorfismo. Os cristais são anedrais a subedrais (com dimensões da ordem de 300 - $500 \mu \mathrm{m}$ ) e são quimicamente classificados, segundo o diagrama de Hey (1954), principalmente como picnocloritas (Figura 7B).

Os cristais de granada analisados da porção W do Grupo Araxá, são geralmente maiores que os cristais de granada do Grupo Araxá na região de Caldas Novas - Rio Quente, possuem dimensões médias da ordem de 2000 a $4000 \mu \mathrm{m}$, raramente atingem dimensões da ordem de $7000 \mu \mathrm{m}$.

A granada ocorre dispersa pela lâmina (cristais isolados), frequentemente os maiores cristais são poiquiloblásticos (inclusões de quartzo, rutilo, plagioclásio, minerais opacos e mais raramente cianita e estaurolita) e, de modo geral, mostram formas anedrais a subedrais (Figura 9B), localmente com bordas alteradas para clorita e biotita. Em alguns cristais poiquiloblásticos as inclusões formam trilhas helicíticas tipo "snow ball", formas sigmoidais, etc. (Figura 9C), indicando crescimento sin-cinemático e desenvolvimento de foliação pretérita ou cedo-desenvolvimento da foliação dobrada. São ricas na molécula de almandina (Alm52,48-79,99) com teores variáveis de grossulária, piropo e espessartita (Figura 8). 

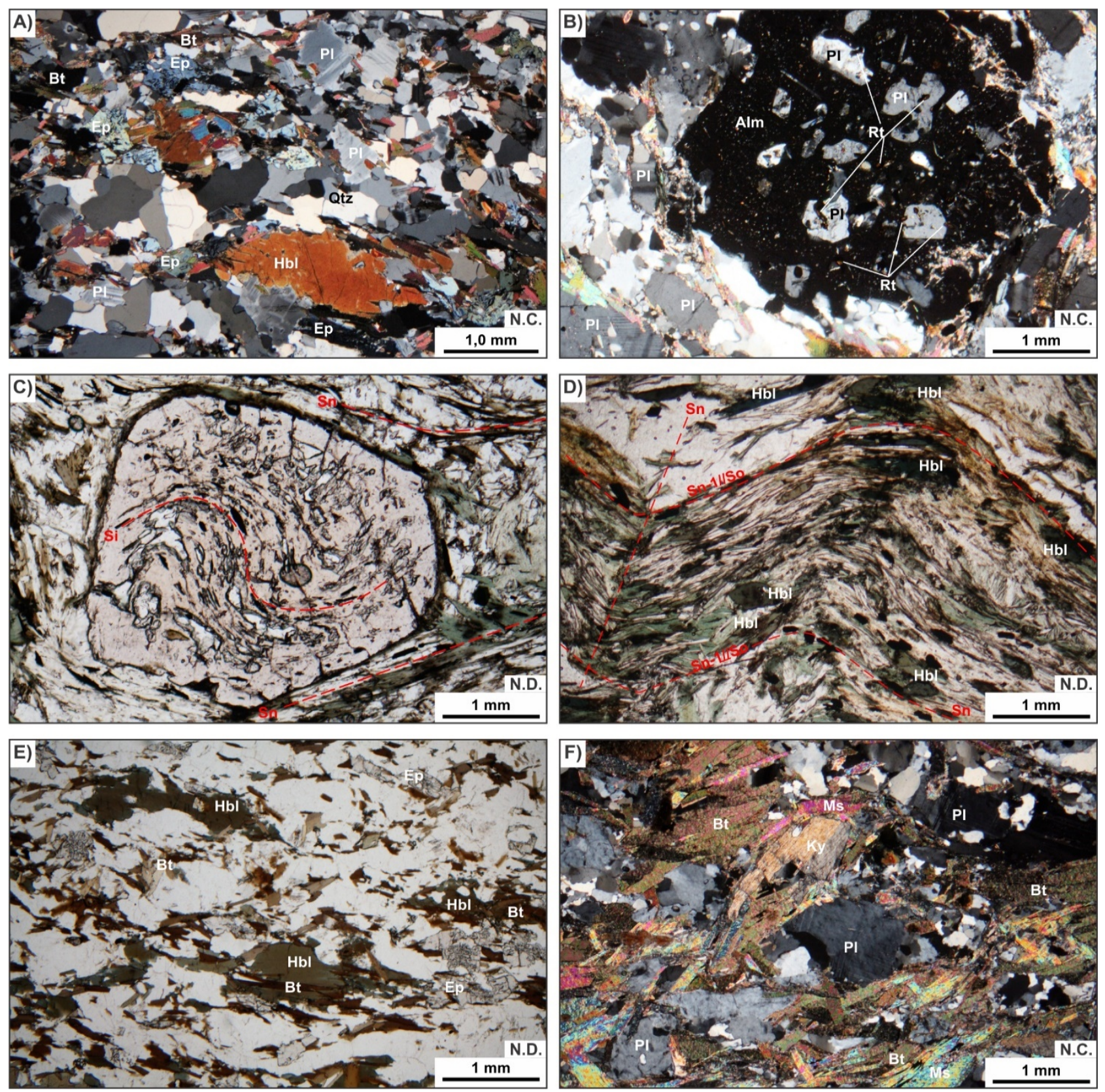

Figura 9 - A) cristais de epidoto em granada-hornblenda-biotita gnaisse. B) cristal de granada poiquilítico com inclusões de plagioclásio e rutilo. C) cristal de granada sin-cinemático com foliação interna (Si) oblíqua a foliação Sn. D) cristais de hornblenda orientados segundo a foliação Sn-1//So. E) cristais de hornblenda parcialmente alterados para biotita. F) cristal de cianita com bordas parcialmente alteradas para muscovita. Alm: almandina. Bt: biotita. Ep: epidoto. Ky: cianita. Hbl: hornblenda. Ms: muscovita. Pl: plagioclásio. Qtz: quartzo. Rt: rutilo. N.D. nicóis descruzados. N.C. nicóis cruzados.

Os cristais de anfibólio ocorrem com dimensões da ordem de 150 a $500 \mu \mathrm{m}$ (localmente podem atingir dimensões da ordem de $1000 \mu \mathrm{m})$ e geralmente ocorrem dispersos nos domínios granoblásticos e lepidoblásticos. São anedrais a subedrais e estão orientados segundo o bandamento composicional (So//Sn1//Sn), localmente deformado pelo esforço que gerou a foliação $\mathrm{Sn}$, indicando que os cristais de anfibólio são pré- a sin-desenvolvimento da foliação Sn, e que a foliação Sn-1 está relacionada ao auge metamórfico (Figura 9D). intercrescidos ou envoltos por clorita e biotita, sugerindo reequilíbrio retrometamórfico (Figura 9E). Quimicamente os cristais de anfibólio não mostram zoneamento químico entre o núcleo e a borda, apenas em alguns cristais observa-se uma leve variação composicional. Esta variação composicional está relacionada ao reequilíbrio retrometamórfico. Possuem 0,001 a 0,224 a.p.u.f. de Ti., 1,488 a 1,908 a.p.u.f. de Ca, 0,041 a 0,681 a.p.u.f. de $\mathrm{Na}, 0,048$ a 0,294 a.p.u.f. de K, e são classificados dominantemente como tschermakita/ferrotschermakita e ferropargasita/ magnésio-

Alguns cristais de anfibólio ocorrem hastingsita (Figura 10). 

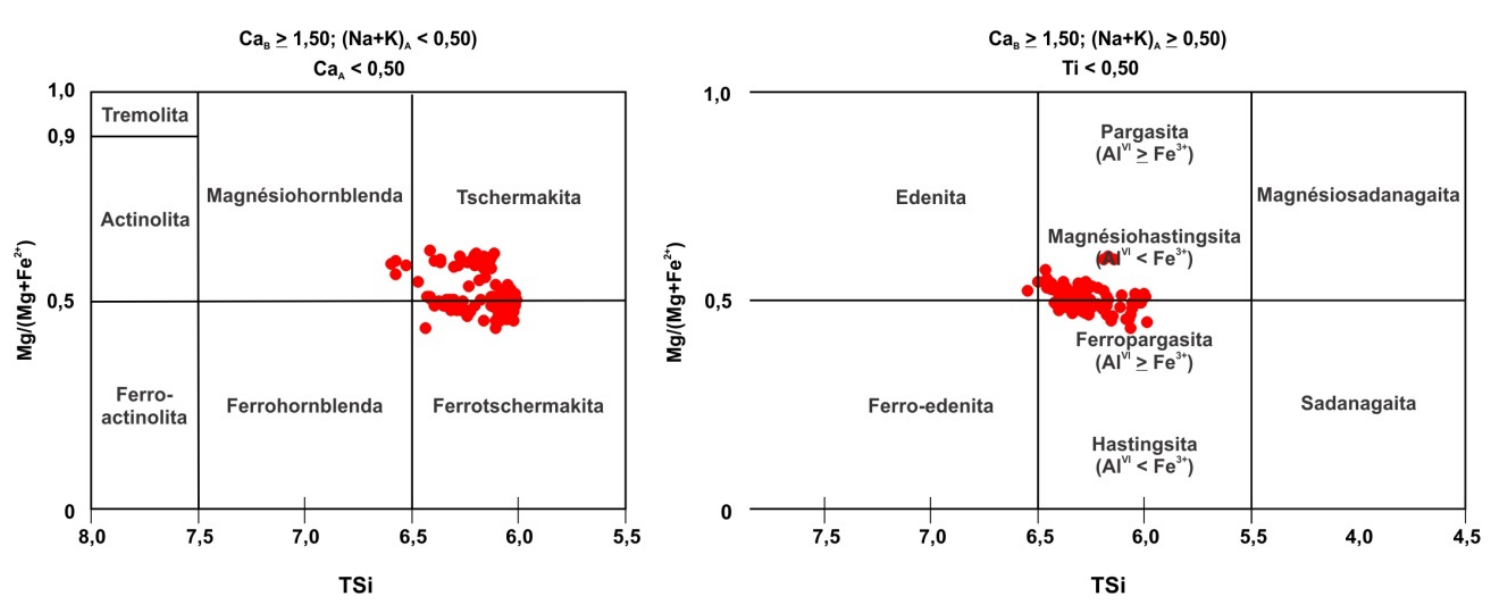

Figura 10 - Diagramas de classificação de cristais de anfibólio analisados. (modificado de Leake et al., 1997).

A cianita possui forma anedral, dimensão média de $1000 \mu \mathrm{m}$ (localmente com dimensões da ordem de $10000 \mu \mathrm{m}$ ) e ocorre dispersa e parcialmente orientada, sempre em proporções menores que $1 \%$, localmente sericitizada ou muscovitizada (Figura 9F).

A estaurolita $(<1 \%)$ possui forma anedral e dimensão média inferior a $1000 \mu \mathrm{m}$, está localmente sericitizada e ocorre em biotita xisto e granada-biotita/muscovita xisto feldspático.

Como minerais acessórios também podem ocorrer: rutilo, titanita, minerais opacos (ilmenita, magnetita, hematita), turmalina, zircão, allanita e apatita. Estes possuem dimensões inferiores a $600 \mu \mathrm{m}$ e ocorrem dispersos pela lâmina, podendo estar orientados, formando trilhas, sendo que normalmente, não ultrapassam $1 \%$ do conteúdo modal. Os cristais de rutilo são prismáticos a arredondados, comumente ocorrem inclusos em cristais de granada, mais raramente na matriz das rochas, e são límpidos e homogêneos.

\section{TERMOBAROMETRIA}

Na região do entorno do Domo de Caldas Novas, as associações minerais relacionadas ao pico metamórfico são típicas da fácies xisto verde superior, caracterizadas por biotita + albita (raramente oligoclásio) + almandina + muscovita; biotita + albita + almandina + muscovita; biotita + albita + almandina; albita + biotita + muscovita, todas contendo quartzo e com ou sem epidoto. A clorita ocorre como cristais dispersos na matriz sugerindo estar em equilíbrio e, em alguns casos, ocorre nitidamente como resultado de retrometamorfismo (na borda de cristais de granada e de biotita). Os cálculos termobarométricos utilizando o software THERMOCALC (Powell \& Holland, 1994) mostram melhor resultado quando a clorita é considerada no cálculo, sugerindo que este mineral está em equilíbrio.

$\mathrm{O}$ auge metamórfico calculado para as amostras do DCN indica temperaturas entre $500^{\circ} \mathrm{C}$ a $570^{\circ} \mathrm{C}$ e pressões entre $7-8$ kbar e sugere que o auge do metamorfismo registrado nas amostras do Grupo Araxá na região de Caldas Novas - Rio Quente ocorreu no campo de estabilidade de cianita, típica da transição da fácies xisto verde superior/anfibolito inferior (Figura 11, Tabela 1). A presença de metabásicas com hornblenda e plagioclásio (andesina/oligoclásio) intercaladas nestes metassedimentos também sugere que o auge metamórfico nesta unidade atingiu condições da fácies anfibolito inferior.

As associações minerais relacionadas ao pico metamórfico nos metassedimentos do Grupo Araxá na região entre Marcelândia - Morrinhos - Rochedo são típicas da fácies anfibolito médio a superior, caracterizadas por biotita + oligoclásio/andesina + almandina + hornblenda; biotita + oligoclásio/andesina + almandina; almandina + oligoclásio/andesina + biotita + cianita, todas contendo quartzo e muscovita, com ou sem rutilo associado.

O pico metamórfico registrado nas rochas do Grupo Araxá é correlacionável à fase deformacional pré- sin- Dn (regional). Os cálculos termobarométricos utilizando o software THERMOCALC (Powell \& Holland, 1994) mostram que o pico metamórfico ocorreu a $600^{\circ} \mathrm{C}-670^{\circ} \mathrm{C}$ e $9-11 \mathrm{kbar}$, em condições $\mathrm{P}-\mathrm{T}$ da fácies anfibolito, zona da cianita (Figura 11, Tabela 1). 

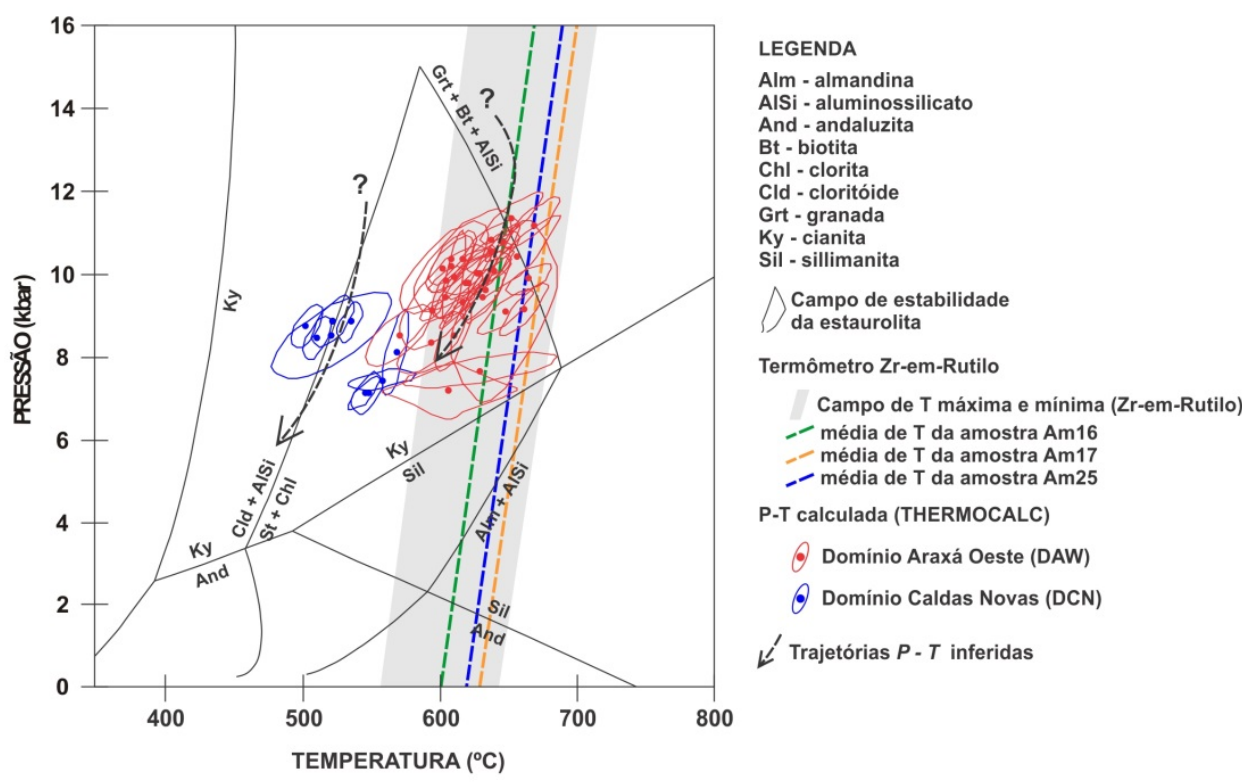

Figura 11 - Diagrama P x T mostrando a trajetória P-T do metamorfismo das rochas do Grupo Araxá no sul do estado de Goiás e os gradientes metamórficos de campo.

Os cálculos com o geotermômetro Zr-emrutilo (calibração de Tomkins et al., 2007) foram feitos para pressões de 9 a $11 \mathrm{kbar}$ em três amostras do Domínio Araxá Oeste. O conteúdo de $\mathrm{Zr}$ dos cristais de rutilo varia de 52 a 474 ppm, e nas condições de 9, 10 e 11 kbar, as temperaturas correspondentes são mínimas de $611^{\circ} \mathrm{C}$ e máxima de $683^{\circ} \mathrm{C}$, de $615^{\circ} \mathrm{C}$ e máxima de $688^{\circ} \mathrm{C}$ e de $619^{\circ} \mathrm{C}$ e máxima de $692^{\circ} \mathrm{C}$ para as pressões fixadas em 9, 10 e 11 kbar, respectivamente (Figura 11). A distribuição dos cristais de diferentes teores não é uniforme, assim como não foi observado homogeneidade nos teores de $\mathrm{Zr}$ em inclusões ou em cristais de matriz.

Os valores de temperatura máxima obtidos pelo geotermômetro $\mathrm{Zr}$ em rutilo são um pouco superiores aos obtidos com o software THERMOCALC, sugerindo que $\mathrm{o}$ auge metamórfico do Grupo Araxá pode ser um pouco superior ao calculado pelo THERMOCALC em trabalhos anteriores (Navarro et al, 2009, 2011) (Tabela 2). Valores de $\log (\mathrm{Cr} / \mathrm{Nb})$ (Zack et al., 2004b; Triebold et al., 2007) ocorrem entre -0,38 a -1,5 e valores do índice $\mathrm{x}\left(\mathrm{x}=5^{*}(\mathrm{Nb}[\mathrm{ppm}]-500)-\mathrm{Cr}[\mathrm{ppm}]\right)$ (Triebold et al., 2012) são positivos, corroborando origem de protólito pelítico para as amostras analisadas.

Embora em ambos conjuntos litológicos os minerais que marcam o auge do metamorfismo marquem a foliação Sn (que no geral é paralela ao bandamento composicional interpretado como $\mathrm{S}_{\mathrm{o}} / / \mathrm{Sn}_{-1}$ ), localmente este bandamento é

cortado pela foliação Sn, indicando que o auge metamórfico é pré- sin- Dn. Este fato também é corroborado pelas inclusões observadas em muitos cristais de granada, que formam trilhas (tipo snow ball, formas sigmoidais, etc.) sem continuidade com a foliação Sn que evolve os porfiroblastos de granada, sugerindo um crescimento pré- sin- Dn.

A trajetória P-T observada em ambos conjuntos é horária, como já sugerido por Navarro et al. (2009, 2011). A trama textural observada em alguns porfiroblastos de granada do Grupo Araxá na região entre Marcelândia Morrinhos - Rochedo - Mairipotaba corroboram com uma trajetória P-T horária para as rochas estudadas. Nestes porfiroblastos de granada, os cristais de plagioclásio variam em composição de $\mathrm{An}_{5}$ no núcleo da granada para $\mathrm{An}_{20-35}$ (composição observada nos cristais de plagioclásio da matriz) na borda dos porfiroblastos, sugerindo um aumento de temperatura durante o crescimento do porfiroblasto das granadas. Também ocorre uma sucessão de inclusões de estaurolita, cianita e sillimanita (fibrolita) do centro para a borda em cristal de granada, que definem uma trajetória $P-T$ progressiva horária.

Os zoneamentos químicos observados em muitos cristais de granada também mostram caminhamento progressivo da trajetória P-T, uma vez que exibem enriquecimento em piropo e almandina e diminuição nas moléculas de espessartita e grossulária do núcleo para a borda. 
Tabela 1 - Resultados das condições P e T do metamorfismo calculados com THERMOCALC.

\begin{tabular}{|c|c|c|c|}
\hline Amostra & $\mathrm{T}^{\circ} \mathrm{C}$ & P (kbar) & Associação Mineral \\
\hline \multicolumn{4}{|c|}{ DCN } \\
\hline Am1 & $518 \pm 11$ & $8,92 \pm 1,62$ & $\mathrm{Alm}+\mathrm{Bt}+\mathrm{Chl}+\mathrm{Ms}+\mathrm{Ab}+\mathrm{Qtz}$ \\
\hline Am2 & $568 \pm 8$ & $8,05 \pm 0,83$ & $\mathrm{Alm}+\mathrm{Bt}+\mathrm{Chl}+\mathrm{Ms}+\mathrm{Olg}+\mathrm{Qtz}$ \\
\hline Am3 & $535+7$ & $8,80 \pm 0,40$ & $\mathrm{Alm}+\mathrm{Bt}+\mathrm{Chl}+\mathrm{Ms}+\mathrm{Ab}+\mathrm{Qtz}$ \\
\hline Am4 & $521+35$ & $8,48+0,84$ & $\mathrm{Alm}+\mathrm{Bt}+\mathrm{Ms}+\mathrm{Ab}+\mathrm{Qtz}$ \\
\hline Am5 & n.c. & n.c. & $\mathrm{Alm}+\mathrm{Bt}+\mathrm{Ms}+\mathrm{Ab}+\mathrm{Qtz}$ \\
\hline Am6 & n.c. & n.c. & $\mathrm{Bt}+\mathrm{Ms}+\mathrm{Chl}+\mathrm{Ab}+\mathrm{Ep}+\mathrm{Qtz}$ \\
\hline $\mathrm{Am} 7 * * *$ & $558 \pm 20$ & $7,40 \pm 0,20$ & $\mathrm{Alm}+\mathrm{Bt}+\mathrm{Chl}+\mathrm{Ab}+\mathrm{Qtz}$ \\
\hline \multicolumn{4}{|c|}{ DAW } \\
\hline Am8 & $634 \pm 12$ & $9,60 \pm 0,50$ & $\mathrm{Hbl}+\mathrm{Alm}+\mathrm{Bt}+\mathrm{Ms}+\mathrm{Ads}$ \\
\hline Am9 & $645 \pm 10$ & $10,73 \pm 0,34$ & $\mathrm{Alm}+\mathrm{Bt}+\mathrm{Ms}+\mathrm{Olg}+\mathrm{Otz}$ \\
\hline Am10 & $632 \pm 12$ & $9,24 \pm 0,49$ & $\mathrm{Hbl}+\mathrm{Alm}+\mathrm{Bt}+\mathrm{Ms}+\mathrm{Olg}+\mathrm{Qtz}$ \\
\hline Am11 & - & - & $\mathrm{Hbl}+\mathrm{Bt}+\mathrm{Ms}+\mathrm{Olg}+\mathrm{Qtz}$ \\
\hline Am12 & $604 \pm 10$ & $9,83 \pm 0,24$ & $\mathrm{Alm}+\mathrm{Bt}+\mathrm{Ms}+\mathrm{Olg}+\mathrm{Ep}+\mathrm{Qtz}$ \\
\hline Am13 & $664+13$ & $9,88+0,31$ & $\mathrm{Alm}+\mathrm{Bt}+\mathrm{Ms}+\mathrm{Ads}+\mathrm{Qtz}$ \\
\hline Am14 & $638+16$ & $10,50+0,40$ & $\mathrm{Hbl}+\mathrm{Alm}+\mathrm{Bt}+\mathrm{Ads}+\mathrm{Czo}+\mathrm{Qtz}$ \\
\hline Am15 & $667 \pm 16$ & $11,20 \pm 0,50$ & $\mathrm{Hbl}+\mathrm{Alm}+\mathrm{Bt}+\mathrm{Ads}+\mathrm{Czo}+\mathrm{Qtz}$ \\
\hline Am16 & $607 \pm 38$ & $7,13 \pm 0,53$ & $\mathrm{Alm}+\mathrm{Bt}+\mathrm{Ms}+\mathrm{Olg}+\mathrm{Qtz}$ \\
\hline Am17 & $629 \pm 45$ & $7,63 \pm 0,35$ & $\mathrm{Alm}+\mathrm{Bt}+\mathrm{Ms}+\mathrm{Ads}+\mathrm{Qtz}$ \\
\hline Am18 & n.c. & n.c. & $\mathrm{Alm}+\mathrm{Bt}+\mathrm{Ms}+\mathrm{Olg}+\mathrm{Qtz}$ \\
\hline Am19 & n.c. & n.c. & $\mathrm{Alm}+\mathrm{Bt}+\mathrm{Ms}+\mathrm{Olg}+\mathrm{Ky}+\mathrm{Qtz}$ \\
\hline Am20* & $570 \pm 19$ & $8,5 \pm 0,6$ & $\mathrm{Alm}+\mathrm{Bt}+\mathrm{Ms}+\mathrm{Olg}+\mathrm{Ky}+\mathrm{Qtz}$ \\
\hline Am21* & $618+19$ & $9,76 \pm 0,69$ & $\mathrm{Alm}+\mathrm{Bt}+\mathrm{Ms}+\mathrm{Ads}+\mathrm{Qtz}$ \\
\hline Am22* & $607 \pm 14$ & $10,20+0,55$ & $\mathrm{Hbl}+\mathrm{Alm}+\mathrm{Bt}+\mathrm{Ms}+\mathrm{Ads}+\mathrm{Qtz}$ \\
\hline Am23* & $609 \pm 14$ & $10,34 \pm 0,54$ & $\mathrm{Hbl}+\mathrm{Alm}+\mathrm{Bt}+\mathrm{Ms}+\mathrm{Ads}+\mathrm{Qtz}$ \\
\hline Am24* & $604 \pm 27$ & $9,4 \pm 1,0$ & $\mathrm{Alm}+\mathrm{Bt}+\mathrm{Ms}+\mathrm{Ads}+\mathrm{Qtz}$ \\
\hline Am26** & $617 \pm 28$ & $10,30 \pm 1,0$ & $\mathrm{Hbl}+\mathrm{Alm}+\mathrm{Bt}+\mathrm{Ms}+\mathrm{Ads}+\mathrm{Czo}+\mathrm{Qtz}$ \\
\hline Am27** & $610 \pm 11$ & $8,50 \pm 0,7$ & $\mathrm{Alm}+\mathrm{Bt}+\mathrm{Ms}+\mathrm{Ads}+\mathrm{St}+\mathrm{Ky}+\mathrm{Qtz}$ \\
\hline Am28** & $603+25$ & $10,10 \pm 0,9$ & $\mathrm{Hbl}+\mathrm{Alm}+\mathrm{Bt}+\mathrm{Ms}+\mathrm{Ads}+\mathrm{Czo}+\mathrm{Qtz}$ \\
\hline Am29** & $594+7$ & $9,10+0,2$ & $\mathrm{Alm}+\mathrm{Bt}+\mathrm{Ms}+\mathrm{Olg}+\mathrm{Qtz}$ \\
\hline Am30** & $610+7$ & $9,90+0,9$ & $\mathrm{Hbl}+\mathrm{Alm}+\mathrm{Bt}+\mathrm{Ms}+\mathrm{Ads}+\mathrm{Czo}+\mathrm{Qtz}$ \\
\hline Am31** & $593 \pm 20$ & $8,30 \pm 0,6$ & $\mathrm{Hbl}+\mathrm{Alm}+\mathrm{Bt}+\mathrm{Ms}+\mathrm{Ads}+\mathrm{Qtz}$ \\
\hline $\begin{array}{l}* \text { dados col } \\
* * \text { dados Cc } \\
* * * \text { dados } \\
\text { n.c.: não ca } \\
\text { Ads: andes } \\
\text { Hbl: hornb }\end{array}$ & $\begin{array}{l}\text { ilados de } \mathrm{T} \\
\text { ipilados de } \\
\text { mpilados d } \\
\text { ulado (resu } \\
\text { a, Alm: alm } \\
\text { ida, Ky: cia }\end{array}$ & $\begin{array}{l}\text { varro et al. (20 } \\
\text { avarro et al. (2 } \\
\text { imões (2005) } \\
\text { dos ruins) } \\
\text { dina, Bt: biotit } \\
\text { ta, Ms: musco }\end{array}$ & $\begin{array}{l}\text { hl: clorita, Czo: clinozoisita, Ep: epidoto, } \\
\text { Olg: oligoclásio, Qtz: quartzo, St: estaurolita. }\end{array}$ \\
\hline
\end{tabular}

Tabela 2 - Resultados das condições P e T do metamorfismo calculados com geotermômetro Zr em rutilo.

\begin{tabular}{|c|c|c|c|c|}
\hline Amostra & $\mathrm{T}^{\circ} \mathrm{C}$ (min.) & $\mathbf{T}^{\circ} \mathbf{C}$ (max.) & P (kbar) & Associação Mineral \\
\hline \multirow[t]{3}{*}{ Am16 } & 648 & 683 & 9 & \multirow{3}{*}{$\mathrm{Alm}+\mathrm{Bt}+\mathrm{Ms}+\mathrm{Olg}+\mathrm{Qtz}$} \\
\hline & 653 & 688 & 10 & \\
\hline & 657 & 692 & 11 & \\
\hline \multirow[t]{3}{*}{ Am17 } & 611 & 674 & 9 & \multirow{3}{*}{$\mathrm{Alm}+\mathrm{Bt}+\mathrm{Ms}+\mathrm{Ads}+\mathrm{Qtz}$} \\
\hline & 615 & 678 & 10 & \\
\hline & 619 & 682 & 11 & \\
\hline \multirow[t]{3}{*}{ Am25 } & 627 & 672 & 9 & \multirow{3}{*}{$\mathrm{Alm}+\mathrm{Bt}+\mathrm{Ms}+\mathrm{Ads}+\mathrm{Qtz}$} \\
\hline & 631 & 676 & 10 & \\
\hline & 635 & 681 & 11 & \\
\hline
\end{tabular}

Ads: andesina, Alm: almandina, Bt: biotita, Ms: muscovita,

Olg: oligoclásio, Qtz: quartzo. 
Nos metassedimentos do Grupo Araxá na região de Caldas Novas, alguns cristais de granada também sugerem trajetória P-T horária. Nestes porfiroblastos de granada, os teores de piropo e almandina aumentam do núcleo para a borda e os teores de grossulária e espessartita diminuem do núcleo para a borda.

Em ambos conjuntos de metassedimentos o retrometamorfismo de caráter regional observado é da fácies xisto verde e caracterezado por:

- crescimento de clorita sobre biotita e granada, por vezes substituindo boa parte dos grãos;

- grandes grãos de muscovita dispostos de forma aleatória sobre a foliação principal;

- saussuritização do plagioclásio;

- muscovitização de cianita e estaurolita,

- alteração de anfibólio para clorita/biotita.

\section{CONCLUSÕES}

As associações minerais observadas, as análises de químicas mineral e os estudos termobarométricos sugerem um zoneamento metamórfico progressivo de E para W no Grupo Araxá na região de Caldas Novas - Morrinhos Rochedo. Na região de Caldas Novas, o feldspato dominante é a albita (raros cristais de oligoclásio), as granadas são pequenas e possuem teores mais baixos de piropo e não ocorre rutilo associado. As associações minerais relacionadas ao auge metamórfico são típicas da fácies xisto verde médio a superior (com indícios que o auge metamórfico atingiu a fácies anfibolito inferior).

À medida que se caminha para $\mathrm{W}$ (próximo a Marcelândia), o plagioclásio dominante passa a ser oligoclásio/andesina e as granadas são maiores e mais ricas em piropo. Na região entre Morrinhos - Rochedo - Mairipotaba, localmente ocorrem xistos/paragnaisses com cianita, estaurolita e hornblenda, e a presença de rutilo é comum, indicando aumento no grau metamórfico. As associações minerais relacionadas ao auge metamórfico são típicas da fácies anfibolito médio a superior.

Os minerais relacionados ao auge metamórfico, em ambos conjuntos, estão orientados segundo o bandamento composicional (So//Sn-1//Sn); localmente este bandamento ocorre dobrado pela crenulação Sn, indicando que o auge metamórfico é pré- a sindesenvolvimento da foliação Sn (regional).

Os dados geoquímicos, isotópicos e idades $\mathrm{U} / \mathrm{Pb}$ em cristais de zircão detríticos indicam que, para ambos conjuntos, a fonte dos sedimentos são rochas ígneas félsicas formadas em arcos magmáticos de idades neoproterozoica e meso-paleoproterozoica, e que pertencem a "uma mesma bacia”, mas depositadas em ambientes diferentes (uma representaria uma porção proximal e a outra distal) (Navarro et al., 2017). Contudo, os dados termobarométricos sugerem que os conjuntos possuem histórias metamórficas diferentes, e que o zoneamento metamórfico é resultado da estruturação tectônica (falhas de empurrão que colocam os metassedimentos de mais alto grau sobre os metassedimentos de mais baixo grau).

\section{AGRADECIMENTOS}

Os autores externam seus agradecimentos pelo apoio da Fundação de Amparo à Pesquisa do Estado de São Paulo (FAPESP), processo 2013/04235-2.

\section{REFERÊNCIAS}

ARAÚJO, V.A.; GODOI, P.V.B.; ARAÚJO, H.O.; MORETON, E.S.; SILVA, L.C.; SA, M.A.D.; MARTINS, A.M.; MATOS, E.G.; ANDRADE, S.H.S.; SALES, R.; BEBERT, C.O.; OlivatTI, O. Projeto Pontalina - Fase I. Goiânia: SURGEO/GO, DNPM, CPRM. 7v., 1980.

BARBOSA, O. Guia das Excursões. In: CONGRESSO BRASILEIRO DE GEOLOGIA, 9, 1955, Araxá. Noticiário n 3...Araxá: Sociedade Brasileira de Geologia, 1955, p. 1-7.

BARBOSA, O.; BAPTISTA, M.B.; INDA, H.; MARCHETTO, M.; ARAÚJO, A.G.; BRAUN, O.P.C.; FRANTIN, O.; CARTNER-DYER, R.; REN, C.; MENEGUESSO, G.; ANDRADE, R.; SEIXAS, S.R.M.; REIS, A.; COTTA, J.C.; SILVA, W.G.; DUTRA, C.V. Projeto Goiânia - Relatório Preliminar. Ministério das Minas e Energia (MME), Departamento Nacional da Produção Mineral (DNPM), $6^{\circ}$ Distrito Centro-Oeste, Prospec S.A. 74 p., 1970b.

BARBOSA, O.; BRAUN, O.P.G.; CARTNER-DYER, R.;
CUNHA, C.A.B. Geologia da Região do Triângulo Mineiro. Ministério das Minas e Energia (MME), Departamento Nacional da Produção Mineral (DNPM), Divisão de Fomento da Produção Mineral (DFPM). Rio de Janeiro, Boletim 136, 210 p., 1970.

DRAKE JR., A.A. The Serra de Caldas windows. Tectonic Studies in the Brazilian shield. U.S. Geological Survev, Protessional Paper, v. 1999-A, B, p. A1-A11, 1980.

FUCK, R.A. \& MARINI, O.J. O Grupo Araxá e unidades homotaxiais. In: SIMPÓSIO SOBRE O CRÁTON DO SÃO FRANCISCO E SUAS FAIXAS MARGINAIS, 1, 1981, Salvador. Anais (Publicação Especial). Salvador: Sociedade Brasileira de Geologia, Núcleo Bahia. 1981, p. 118-130, 1981. HASUI, Y. Sistema Orogênico Tocantins. In: HASUI, Y.; CARNEIRO, C.D.R.; ALMEIDA, F.F.M.; BARTORELLI, A. (EDS), Geologia do Brasil. São Paulo: Ed. Beca. p.289-325, 2012.

HEY, M.H. A new review of the chlorites. The Mineralogical 
Magazine, v. 30, p. 277-292, 1954.

IANHEZ, A.C.; PITTHAN, J.H.L.; SIMÕES, M.A.; DEL ÀRCA, J.O.; TRINDADE, C.A.H.; LUZ, D.S. FERNANDES, C.A.C. Geologia. Brasil. Ministério das Minas e Energia. Projeto RADAM BRASIL: Folha SE.22 Goiânia, Rio de Janeiro: MME-SG, v. 31, p. 23-348 (Levantamentos de Recursos Naturais, 31), 1983.

KLEIN, P.B.W. Geoquímica de rocha total, geocronologia de $\mathrm{U}$ - Pb e geologia isotópica de $\mathrm{Sm}$ - Nd das rochas ortognáissicas e unidades litológicas associadas da região de Ipameri - Catalão (Goiás). Brasília, 2008. 154 p. Tese (Doutorado em Geociências) - Instituto de Geociências, Universidade de Brasília.

LACERDA FILHO, J.V.; REZENDE, A.; SILVA, A. Programa de Levantamentos Geológicos Básicos do Brasil - Geologia e Recursos Minerais do Estado de Goiás e Distrito Federal. 1:500.000. $2^{0}$ edição. Goiânia: Conv. CPRM - Superintendência Regional de Goiânia/METAGO S.A./UnB, 184 p., 1999.

LEAKE, B.E.; WOOLLEY, A.R.; ARPS, C.E.S.; BIRCH, W.D.; GILBERT, M.C.; GRICE, J.D.; HAWTHORNE, F.C.; KATO, A.; KISCH, H.; KRIVOVICHEV, V. G.; LINTHOUT, K.; LAIRD, J.; MANDARINO, J.A.; MARESCH, W.V.; NICKEL, E.; ROCK, N.M.S.; SCHUMACHER, J.C.; SMITH, D.C.; STEPHENSON, N.C.N.; UNGARETTI, L.; WHITTAKER, E.J.W.; YOUZHI, G. Nomenclature of amphiboles: report of the subcommittee on amphiboles of the International Mineralogical Association, commission on new minerals and mineral names. The Canadian Mineralogist, n. 35, p. 219-246, 1997.

MOREIRA, M.L.O.; MORETON, L.C.; ARAÚJO, V.A.; LACERDA FILHO, J.V.; COSTA, H.F. Geologia do Estado de Goiás e Distrito Federal. 1:500.000. Programa Geologia do Brasil: Integração, Atualização e Difusão de Dados de Geologia do Brasil. Programa Geologia e Mineração do Estado de Goiás: Geração e Disponibilização de Informações Geológicas e do Potencial Mineral de Goiás. Goiânia: CPRM/SIC - FUNMINERAL, 141 p., 2008.

NAVARRO, G.R.B. \& ZANARDO, A. Geoquímica de Gnaisses do Arco Magmático de Goiás na Região Sul do Estado de Goiás. Geologia USP, Série Científica, v. 7, n. 1, p. 19-28, 2007.

NAVARRO, G.R.B.; MORAES, R.; ZANARDO, A.; SIMÕES, L.S.A.; CONCEIÇÃO, F.T. Trajetória $P-T$ e condições do metamorfismo usadas como ferramenta para compartimentação tectônica da Faixa Brasília em Goiás. Revista Brasileira de Geociências, v. 39, n. 3, p. 554-559, 2009.

NAVARRO, G.R.B.; ZANARDO, A.; CONCEIÇÃO, F.T. O Grupo Araxá na Região Sul-Sudoeste do Estado de Goiás. Geologia USP, Série Científica, v. 13, n. 2, 5-28, 2013.

NAVARRO, G.R.B.; ZANARDO, A.; CONCEIÇÃO, F.T. Orto-gnaisses peraluminosos associados ao Grupo Araxá na região de Rochedo, Goiás. Unesp, Geociências, v. 33, n. 4, p. 672-685, 2014a.

NAVARRO, G.R.B.; ZANARDO, A.; CONCEIÇÃO, F.T. Ortognaisses peraluminosos associados ao Grupo Araxá na região de Mairipotaba-Prof. Jamil Safady, Goiás. Brazilian Journal of Geology, v. 44, n. 2, p. 235-248, 2014b.

NAVARRO, G.R.B.; ZANARDO, A.; CONCEIÇÃO, F.T.; MORAES, R.; SIMÕES, L.S.A. Química Mineral e Estimativas de Pressão e Temperatura em Rochas Metassedimentares do Grupo Araxá na Região de Morrinhos, Sul do Estado de Goiás. Geologia USP, Série Científica, v. 11, n. 2, p. 3-20, 2011.

NAVARRO, G.R.B.; ZANARDO, A.; MONTIBELLER, C.C.; CONCEIÇÃO, F.T.; VALERIANO, C.M.; LEME, T.G.; SIMÕES, L.S.A. Proveniência dos metassedimentos do Grupo Araxá na região de Caldas Novas, Goiás. Geociências, v. 36, n. 2, p. 395-413, 2017.
NAVARRO, G.R.B.; ZANARDO, A.; MONTIBELLER, C.C.; CONCEIÇÃO, F.T.; LEME, T.G.; VALERIANO, C.M. Proveniência das rochas metassedimentares do Grupo Araxá na porção central da Faixa Brasília. Geociências, submetido, 2018.

PIMENTEL, M.M. \& FUCK, R.A. Neoproterozoic crustal accretion in central Brazil. Geology, v. 20, p. 375-379, 1992.

PIMENTEL, M.M.; FUCK, R.A.; SILVA, J.L.H. Dados Rb-Sr e Sm-Nd da região de Jussara-Goiás-Mossâmedes (GO), e o limite entre terrenos antigos do Maciço de Goiás e o Arco Magmático de Goiás. Revista Brasileira de Geociências, v. 26, p. 61-70, 1996.

PIMENTEL, M.M.; FUCK, R.A.; BOTELHO, N.F. Granites and the geodynamic history of the Neoproterozoic Brasília Belt, Central Brazil: a review. Lithos, v. 46, n. 3, p. 463-483, 1999.

PIMENTEL, M.M.; DARDENNE, M.A.; FUCK, R.A.; VIANA, M.G.; JUNGES, S.L.; FISCHEL, D.P.; SEER, H.J.; DANTAS, E.L. Nd isotopes and the provenance of detrital sediments of the Neoproterozoic Brasília Belt, central Brazil. Journal of South American Earth Sciences, v. 14, p. 571585, 2001

PIUZANA, D.; PIMENTEL, M.M.; FUCK, R.A., ARMSTRONG, R.A. SHIRIMP U-Pb and Sm-Nd data for the Araxá Group and associated magmatic rocks: constraints for the age of sedimentation and geodynamic context of the southern Brasília Belt, central Brazil. Precambrian Research, v. 125, p. 139-160, 2003.

POWELL, R. \& HOLLAND, T. Optimal geothermometry and geobarometry. American Mineralogist, v. 79, p. 120-144, 1994.

SATO, K. Evolução crustal da Plataforma Sul Americana, com base na geoquímica isotópica Sm-Nd. São Paulo, 1998. 297 p. Tese (Doutorado) -Instituto de Geociências, Universidade de São Paulo.

SIMÕES, L.S.A. Compartimentos Crustais do Domínio Interno da Faixa Brasília no sul do estado de Goiás. Rio Claro. 2005. 104 p. Tese (Livre Docência), Instituto de Geociências e Ciências Exatas - Universidade Estadual Paulista.

SIMÕES, L.S.A.; NAVARRO, G.R.B.; HACKSPACHER, P.C.; ANGELI, N. Estruturas precoces ao desenvolvimento da foliação principal da Faixa Brasília: o exemplo de Caldas Novas, Goiás. In: SIMPÓSIO NACIONAL DE ESTUDOS TECTÔNICOS, 9, 2003, Rio de Janeiro. Boletim de Resumos. Rio de Janeiro: SBG, Núcleo Rio de Janeiro-Espirito Santo, 2003, p. 105-107.

TOMKINS, H.S.; POWELL, R.; ELLIS, D.J. The pressure dependence of the zirconium in rutile thermometer. Journal of Metamorphic Geology, v. 25, p. 703-713, 2007.

TRIEBOLD, S.; VON EYNATTEN, H.; LUVIZOTTO, G.L.; ZACK, T. Deducing source rock lithology from detrital rutile geochemistry: an example from the Erzgebirge, Germany. Chemical geology, v. 244, n. 3-4, p. 421-436, 2007.

TRIEBOLD, S.; VON EYNATTEN, H.; ZACK, T. A recipe for the use of rutile in sedimentary provenance analysis. Sedimentary Geology, v. 282, p. 268-275, 2012.

VALENTE, C.R. Projeto Mapas Metalogenéticos e de Previsão de Recursos Minerais. Folha Morrinhos, SE.22X-D. Brasília: DNPM, CPRM, SRG. 18 p., 1986.

ZACK, T.; MORAES, R.; KRONZ, A. Temperature dependence of $\mathrm{Zr}$ in rutile: empirical calibration of a rutile thermometer. Contributions to Mineralogy and Petrology, v. 148, p. 471-488, 2004a.

ZACK, T.; VON EYNATTEN, H.; KRONZ, A. Rutile geochemistry and its potential use in quantitative provenance studies. Sedimentary Geology, v. 171, n. 1-4, p. 37-58, 2004b

Submetido em 23 de setembro de 2018 Aceito em 3 de fevereiro de 2019 